\title{
IMF-Supported Programs and Sovereign Debt Crises
}

\author{
Hippolyte Balima ${ }^{1,2} \cdot$ Amadou Sy $^{1}$
}

Published online: 23 February 2021

(C) International Monetary Fund 2021

\begin{abstract}
This paper studies the role of IMF-supported programs in mitigating the likelihood of subsequent sovereign defaults in borrowing countries. Using a panel of 106 developing countries from 1970 to 2016 and an entropy balancing methodology, we find that IMF-supported programs significantly reduce the likelihood of subsequent sovereign defaults. This finding is robust to different specifications of the entropy balancing and alternative identification strategies. Our results suggest that a country that signs a program with the IMF typically experiences a slight improvement in its sovereign credit rating and a decrease in both government debt-to-GDP and fiscal deficit-to-GDP during the program period compared to the period before.
\end{abstract}

\section{Introduction}

Growing debt vulnerability is not a new challenge for many countries. Four years before the Covid-19 pandemic, global debt reached a record peak of $225 \%$ of world GDP, an increase of $12 \%$ points of GDP compared to the previous peak at the onset of the 2007 financial crisis (IMF 2018). But as the pandemic spread, median debt in 2021 is projected to increase by about $17 \%$ of GDP in advanced economies, $12 \%$ in emerging economies and $8 \%$ in low-income countries compared to pre-pandemic expectations - as countries face higher spending to combat the pandemic and lower revenue due to automatic stabilizers (IMF 2020). High government debts expose countries to rollover risks and to a sudden tightening of international financial

\footnotetext{
We are grateful to the Editor, Linda Tesar, anonymous referees, Emre Alper, Karim Barhoumi, Ehsan Ebrahimy, Axel Schimmelpfennig and participants of the IMF's African Department Financial and Monetary Policy Network for their helpful comments. All remaining errors are our own.
}

Hippolyte Balima

HBalima@imf.org

Amadou Sy

ASy@imf.org

1 International Monetary Fund (IMF), Washington, DC, USA

2 CNRS, LEO, University of Orleans, Orléans, France 
conditions - and therefore to increased risk of subsequent default. An important policy question is whether the Fund, in its mandate of providing financial support mechanisms to member countries that are experiencing actual or potential macroeconomic problems through bailout mechanisms, can help mitigate the occurrence of such subsequent crises. In this paper, we study the role of bailouts in mitigating the likelihood of subsequent sovereign defaults in developing countries, taking IMFsupported programs as an example.

In theory, the mechanisms through which IMF-supported programs can affect sovereign debt crises are not obvious. IMF loans may affect sovereign defaults through conflicting channels (Jorra 2012). A first mechanism may arise from the consequences of liquidity provisions, particularly in the context of an illiquid government. If a government is facing a temporary liquidity shortage, having a rescue from the Fund may ease its liquidity constraints and help avoid a potential self-fulfilling crisis (Fisher 1997). In addition to mitigating liquidity constraints, the Fund's support may also catalyze investor participation through improved confidence-thus helping to mobilize capital from other sources (Dhonte 1997; Fisher 1997; Bird and Rowlands 2002; Tirole 2002; Morris and Shin 2006; Saravia 2010). However, the catalytic effect on private lenders could come at a cost in the long run if the government ends up accumulating a higher level of private debt (Fink and Scholl 2016). Second, IMF-supported programs may affect debt crises through the policy adjustment channel. If countries do not pay for the consequences of their policy actions because of insurance provided by the Fund - on account of emergency loans that are somewhat cheaper than market conditions - this may create a moral hazard as countries may be (more) reluctant to undertake necessary but painful fiscal adjustments. A moral hazard may particularly arise if the Fund fails to differentiate between temporary liquidity crises and permanent ones (Vaubel 1996; Dreher 2004). Finally, a third mechanism, linked somewhat to the previous channel, is the role of conditionalities in IMF programs. Conditionalities, if properly tailored and implemented, may help rebuild a stable and sustainable macroeconomic position, including an improved fiscal position. Consequently, the question of whether IMF-supported programs have a positive or a negative effect on the likelihood of occurrence of debt crises is an empirical one.

The paper's empirical assessment relies on a large and representative panel of 106 developing countries over the period 1970-2016. We address the common issue of identification in IMF program evaluation using different strategies. In our benchmark approach, we employ the entropy balancing methodology, a generalization of conventional matching methods proposed by Hainmueller (2012), and recently used by Neuenkirch and Neumeier (2016) to study the impact of U.S. sanctions on poverty, and by Balima (2017) to analyze the effect of domestic sovereign bond market participation on financial dollarization. While the relative performance of entropy balancing — compared to alternative methods - will be closely discussed in detail in the methodological section, this method allows us to identify the impact of Fundsupported programs by comparing program and nonprogram countries that are as similar as possible in terms of observable characteristics, after purging for country- and time-specific factors. In robustness checks, we also employ an instrumental variable approach and conventional matchings. Our instrumental variable strategy 
uses two political variables-borrower's ties with the Fund's major shareholders at the United Nations General Assembly and previous executive elections-as external instruments for a country decision to sign a program with the Fund. The matching approaches employ propensity scores matching and bias-corrected matching to deal with the selection bias in Fund program adoption.

The main finding in this paper indicates that IMF-supported programs significantly reduce the likelihood of subsequent sovereign defaults by around $1.3 \%$ points. This estimated coefficient is economically meaningful given that the unconditional probability of experiencing a sovereign default is about $3.5 \%$ points in our sample. We demonstrate that our finding is particularly robust to different specifications of the entropy balancing and the use of additional identification strategies including an instrumental variable approach and conventional matchings. Moreover, we find that a country that signed a program with the Fund experienced a slight improvement in its sovereign credit rating and a decrease in both government debt-to-GDP and fiscal deficit-to-GDP during the program period compared to the period before. This suggests that (i) the liquidity provision channel and catalytic role, (ii) the role of government adjustment effort, and (iii) the conditionality channel may be at work. Our results are in line with the theoretical model of Corsetti et al. (2006) that shows that a lending support not only has an impact on the likelihood and the possible incidence of a crisis, but also prompts the borrowing government to implement desirable policies and reforms.

The rest of the paper is as follows. Section 2 discusses the existing literature. Section 2 presents our benchmark empirical methodology. Section 4 describes the data. Section 5 reports the baseline result while Sect. 6 follows with the robustness checks. Section 7 provides some potential explanations of the result. Finally, a summary is presented in Sect. 8 .

\section{Literature Review}

Existing theoretical literature on this issue, starting from Eaton and Gersovitz (1981), focuses more broadly on bailout programs by International Financial Institutions (IFIs) in models of strategic sovereign defaults (Zettelmeyer 2000; Corsetti et al. 2006; Boz 2011; Fink and Scholl 2016). Zettelmeyer (2000) uses a static coordination game model and suggests that limited rescue packages can have counterproductive effects in the short run by providing investors the opportunity to exit. Corsetti et al. (2006) provide an opposite view. Using a model in which a crisis can be the outcome of fundamental shocks and self-fulfilling panics, they show that partial bailouts conditional on policy adjustment by the debtor country can restore investors' confidence and therefore reduce the incidence of crises. Their model also shows that liquidity support can tilt the government's incentives to implement desirable but costly policies and reforms. Boz (2011) shows that sovereigns borrow more from private sector creditors compared to IFIs - even if the interest rates charged by the latter are significantly lower-because they can strategically default on private debt, whereas IFI's debt contracts are enforceable. Fink and Scholl (2016) formalize a dynamic stochastic model of sovereign debt and default with endogenous 
participation rates in bailout programs and calibrate the model to Argentina. They show that bailouts lower the likelihood of a sovereign default in the short run and restore the confidence of private lenders through increasing their willingness to provide new credit to the borrowing government. In their framework, the government then takes advantage of the catalytic effect induced by bailouts-lower interest rates, larger capital supply - and accumulates more private debt. As a result, the risk of default increases in the long run.

On the empirical side, the literature is, however, relatively sparse. A notable exception is Jorra (2012) who analyzes the effect of IMF bailouts on the probability of subsequent sovereign defaults. Using a sample of 57 developing economies, he finds that IMF-supported programs increase the probability of subsequent sovereign defaults by approximately $1.5-2 \%$ points. The author stresses that his result cannot be attributed to an endogeneity bias or a lack of compliance with IMF conditionality, as his empirical specification explains simultaneously sovereign defaults and program participation. Apart from Jorra (2012), previous empirical studies analyzing the direct association between bailouts in the context of IMF lending programs and crises focus on three types of crises: sudden stops, currency crises, and banking crises (Eichengreen et al. 2006; Dreher and Walter 2010; Papi et al. 2015). Eichengreen et al. (2006) examine the impact of IMF-supported programs on the incidence of sudden stops in capital flows. After correcting for the non-random assignments of IMF programs, they find that IMF credit reduces the likelihood of sudden stopsparticularly for countries with strong fundamentals-through the stabilizing effect of liquidity insurance. Dreher and Walter (2010) employ a panel of 68 countries over the period 1970-2002. They show that IMF involvement decreases a country's risk of experiencing a currency crisis through the presence of the Fund itself rather than money disbursements or compliance with conditionality. Finally, in a recent paper, Papi et al. (2015) focus on banking crises, using a large panel of 113 developing countries over the period 1970-2010. The empirical assessment concludes that, after correcting for endogeneity issues, countries which signed IMF-supported programs are less likely to experience a banking crisis.

However, the empirical assessment of IMF-supported programs and sovereign defaults_-Jorra (2012) — is not immune from criticism. First, Jorra's focus is on emerging market economies with market access, as his paper's motivation comes from the IMF involvement in Greece, which did not help improve bond spreads. Based on that, Jorra uses more selective measures of stand-by arrangement and extended fund facility programs and his broadest measure of IMF programs (which includes programs to low-income countries-LICs, i.e., poverty reduction and growth facility and structural adjustment facilities) is only significant at $10 \%$ in the regression. Therefore, Jorra paper's main analysis excludes poverty reduction and growth facilities and their predecessors, the structural adjustment facilities programs on the basis that such programs are targeted to LICs with little access to private capital markets. But the sovereign debt landscape and the type of IMF programs have changed over time. Many low-income countries have now market access and 
should be included in the sample. ${ }^{1}$ The IMF has also come up with new types of programs for LICs and most LICs are now under an extended credit facility, not included in Jorra's analysis. In addition, we are now in a situation where countries have both market financing from the Eurobond market and access to concessional financing from the IMF. Second, and in relation to the previous point, Jorra's definition of a debt crisis is taken from Standard and Poor's, and therefore focuses on the selected countries' defaults on marketable debt. Thus, it excludes defaults with official creditors. Third, while Jorra's empirical identification uses a pooled probit model and a pooled bivariate probit - a version of Heckman two-step approach. But such a strategy has two limitations: (i) it does not control for unobservable factors and unaccounted observable characteristics, and (ii) it may be subject to inconsistent estimates if collinearity problems prevail (Puhani 2002). ${ }^{2}$ Finally, given the above evidence from Eichengreen et al. (2006), Dreher and Walter (2010), and Papi et al. (2015), a natural question emerges. Why should IMF involvement lower the likelihood of sudden stops, currency crises and banking crises, while increasing the risk of sovereign defaults?

\section{Methodology}

\subsection{The entropy Balancing Framework}

The objective of this paper is to analyze the role of bailouts in mitigating the likelihood of subsequent sovereign debt crises (SDC) in borrowing countries, taking IMF-supported programs as an example. Our challenge is to establish a causal link running exclusively from the implementation of a Fund program to the occurrence of an SDC. As stressed by Bird (2001) and Dreher and Walter (2010), empirical studies of the impact of IMF programs commonly faced the problem of counterfactual and endogeneity. On the one hand, it is hard to properly predict the outcome that would have emerged without a program and to quantify the impact induced by program participation. On the other hand, countries usually turn to the Fund during times of economic downturn - in particular when a crisis is looming-due to the Fund's mandate of being the international lender of last resort. Some previous studies deal with these issues by employing a version of Heckman (1979) two-step estimator or an instrumental variable approach (Przeworski and Vreeland 2000; Hardoy 2003; Barro and Lee 2005; Conway 2006; Jorra 2012). Other studies also use conventional matching methodologies (Mumssen et al. 2013; Gündüz 2016).

In this paper, we employ the entropy balancing methodology—a generalization of conventional matching methods proposed by Hainmueller (2012)—-to overcome

\footnotetext{
${ }^{1}$ For instance, Jorra's paper includes 6 African countries with market access. But at least 21 African countries have now issued Eurobonds.

2 In contrast, as discussed later in Sect. 3.2., the entropy balancing allows us to control for unobservable factors. Also, the entropy balancing, as a nonparametric method, does not impose a functional form and therefore does not suffer from multicollinearity.
} 
the counterfactual and endogeneity issues with regard to the adoption of an IMF program. This methodology has been recently used by Neuenkirch and Neumeier (2016) to assess the impact of U.S. sanctions on poverty, and by Balima (2017) to analyze the effect of domestic sovereign bond market participation on financial dollarization. Entropy balancing allows us to identify the impact of IMF-supported programs by comparing program and nonprogram countries that are as similar as possible in terms of observable characteristics, after purging for country- and timespecific factors.

The entropy balancing approach is based on the idea that the adoption of an IMFsupported program represents the treatment variable and the occurrence of an SDC represents the outcome variable. The units of observations are country-year observations; observations with (without) a program represent the treatment (control) group. The measure of interest we wish to estimate is the well-known average treatment effect on the treated, $\tau$, defined as

$$
\tau=E\left[\mathrm{SDC}_{(1)} \mid P=1\right]-E\left[\mathrm{SDC}_{(0)} \mid P=1\right]
$$

where $\mathrm{SDC}_{(.)}$is the outcome variable measuring the occurrence of a sovereign debt crisis. $P$ indicates if the unit of observation is subject to the treatment $I M F$-supported program $(P=1)$ or not $(P=0)$. Consequently, $E\left[\mathrm{SDC}_{(1)} \mid P=1\right]$ is the probability of experiencing a sovereign default during the program period and $E\left[\mathrm{SDC}_{(0)} \mid P=1\right]$ is the counterfactual outcome for countries that signed programs-the likelihood of experiencing sovereign defaults in program countries if they had not adopted programs. ${ }^{3}$ Given that we cannot observe the last one, we need to identify an appropriate proxy. If a program adoption was a random event, we could easily identify $\tau$ by comparing $S D C$ in program and nonprogram countries. However, as discussed earlier, the decision to request a program from the Fund is rather endogenous to several macroeconomic variables. For this reason, we can compare-after purging for some specific factors-program and nonprogram units that are as close as possible with respect to observable characteristics that meet these two conditions: (i) they are correlated with a country's decision to sign a program with the Fund and (ii) they are associated with the occurrence of an SDC. Under the condition that the nonprogram units are as similar as possible to the program units, the difference in $S D C$ is caused by the adoption of an IMF-supported program. With these remarks, the above equation can then be rewritten as follows:

$$
\tau=E\left[\mathrm{SDC}_{(1)} \mid P=1, X=x\right]-E\left[\mathrm{SDC}_{(0)} \mid P=0, X=x\right]
$$

where $X=x$ is a vector of observable covariates that may affect both a country's decision to sign a program and the likelihood of experiencing a default, as described in the data section below. $E\left[\operatorname{SDC}_{(1)} \mid P=1, X=x\right]$ is the likelihood of a default

\footnotetext{
${ }^{3}$ Equation (1)'s intended objective is to compare the probability of experiencing a sovereign default during the program period- $-E\left[S D C_{(1)} \mid P=1\right]$, and the counterfactual outcome for countries that signed programs $-E\left[S D C_{(0)} \mid P=1\right]$ or the likelihood of experiencing sovereign defaults in program countries if they had not adopted programs.
} 
occurrence for program units, and $E\left[\mathrm{SDC}_{(0)} \mid P=0, X=x\right]$ is the expected likelihood of experiencing a default for the synthetic control units.

Practically, to estimate $\tau$ with the entropy balancing, we follow two consecutive steps. A first step computes weights for nonprogram units. These weights should satisfy pre-specified balanced constraints involving sample moments of observable characteristics, X. Following Neuenkirch and Neumeier (2016), the balance constraints impose equal covariate means across program and nonprogram groups. By doing so, we ensure that the nonprogram group contains, on average, units not subject to a program that are as similar as possible to the program units. In the robustness exercises, we will also bring the 2 nd and the 3rd moments into the list of the balanced constraints. A second step uses the first step's weights in a regression analysis where SDC is the dependent variable and the IMF-supported program dummy is the main explanatory variable. We then estimate the average treatment effect of $\mathrm{IMF}$ programs on SDC, $\tau$. In the second step, we also control for the entropy balancing covariates as well as time and regional specific effects-as in a randomized experiment- to increase the efficiency of the estimates.

\subsection{The Advantages of Entropy Balancing}

Entropy balancing has some advantages over other treatment effect estimators or regression analyses (Hainmueller 2012). Its most attractive feature is to allow a high degree of covariate balance between program and nonprogram groups-even in small samples-by creating a synthetic control group that is as close as possible to the program group. ${ }^{4}$ With "conventional" matching methods such as nearest neighbor matching or propensity score matching, each treated unit-in the simplest case-is matched with the one untreated unit that is closest in terms of the balancing score. Accordingly, the control group is comprised of only a subset of the units that are not subject to the treatment (Diamond and Sekhon 2013; Hainmueller 2012). Put differently, with conventional matching methods, each untreated unit either receives a weight equal to 0 , in the event it does not represent a best match for a treated unit, or equal to 1 , in the event it does represent a best match for one treated unit. However, with a limited number of untreated units and a large number of pretreatment characteristics, this procedure does not guarantee a sufficient balance of pretreatment characteristics across the treatment and control groups. This is a serious problem, as a low covariate balance may lead to biased treatment effect estimates. In contrast, with entropy balancing, the vector of weights assigned to the units not exposed to the treatment can contain nonnegative values. Thus, a synthetic control group is designed to represent a comparable image of the treatment group. Entropy balancing thus can be interpreted as a generalization of conventional matching approaches.

\footnotetext{
${ }^{4}$ Hainmueller (2012), in a Monte Carlo simulation, compares the performances of entropy balancing to other alternative impact assessment methodologies, including propensity score matching and genetic matching. He concludes that entropy balancing outperforms these alternative methodologies in terms of estimation bias and mean square error.
} 
A second advantage is that, compared to simple regression-based approaches (namely difference-in-differences) or conventional matching methods (including propensity scores and bias-corrected matchings), entropy balancing is non-parametric. In this sense, entropy balancing is fairly versatile as its use does not require specifying an empirical model for the adoption of an IMF program or the outcome variable. This feature makes it possible to minimize potential problems of misspecifications like those arising when choosing a functional form of an empirical model. In contrast to regression-based analyses, the entropy balancing estimates do not suffer from multicollinearity because its reweighting scheme orthogonalizes the covariates with respect to the treatment measure-the adoption of IMF-supported programs.

A third advantage is that, compared to conventional matching where the control units are either discarded or matched, entropy balancing uses more flexible reweighting schemes. It reweights units with the goal of achieving balance between treated and untreated while keeping the weights as close as possible to the base weights to avoid a loss of information. Finally, conventional matching methods and pooled probit models rely on the conditional independence assumption-that is, based on a vector of observable covariates, the treatment is independent of unobservable factors. However, using the entropy balancing allows us to consider the panel dimension of the data by controlling for country- and time-specific factors in the second step of the regression analysis. ${ }^{5}$ The inclusion of country-fixed effects is particularly helpful in accounting for potential unobserved heterogeneity across countries that have never adopted IMF-supported programs and those that have adopted them. Indeed, the macroeconomic environment of these two groups may differ beyond the set of covariates employed in the entropy balancing approach. Country-fixed effects also control for time-invariant country-specific conditions that might lead to differences in the likelihood of experiencing debt crises across countries.

While our preferred method is the entropy balancing, later in the paper, we also employ a battery of alternative identification strategies including an instrumental variable approach and conventional matching methodologies, to validate our findings.

\section{Data}

We use a large panel dataset covering 106 developing countries over the period 1970-2016. We focus exclusively on developing countries to reduce the scope for parameter instabilities owing to differences in structural and institutional conditions in program and nonprogram countries (Dicks-Mireaux et al. 2000). The dependent variable is a dummy indicating the occurrence of a sovereign debt crisis. This variable is taken from the database on government debt in default developed by

\footnotetext{
5 Some previous studies including Jorra (2012) use a pooled probit due to the incident parameter problem resulting from applying a least square dummy variable estimator to a model with a binary dependent variable.
} 
the credit rating assessment group (CRAG) of the Bank of Canada; the latest version of the database is provided by Beers and Mavalwalla (2017). We prefer this database due to its relative comprehensiveness and to the frequency of occurrence of sovereign defaults, compared to the existing concurrent database. The Bank of Canada's CRAG database has been recently used by Eichengreen (2015), Reinhart and Trebesch (2016) and Reusens and Croux (2017). In a robustness check, we also use the Laeven and Valencia database. The CRAG database compiles a comprehensive global dataset of official government debt on defaults and the stock of arrears with official creditors using different sources including international and regional organizations (i.e., the Asian Development Bank, the IMF, the Paris Club, the World Bank, and the IBRD's annual financial statements) and academic authors. ${ }^{6}$ In particular, the CRAG database gathers previously published datasets compiled by various sources together with new information, which makes it one of the most comprehensive dataset on sovereign defaults currently available. Consistent with previous literature on sovereign defaults (Reinhart and Rogoff 2011; Cruces and Trebesch 2013), a default is defined when a debt service is not paid on the due date or within a specified grace period, or conditions. However, given that the final resolution with creditors following a sovereign default can be very lengthy, we follow Reinhart and Rogoff (2011) and consider only the first year of default as a crisis year. By doing so, we identify 115 sovereign debt crises in our sample, the first event in 1976 and the last in 2016. The average number of crises per year is about two events, with some peaks in 1980, 1985, 1998, 2008, and 2013.

Information on our treatment variable, IMF-supported programs, is drawn from the "Fund Arrangements since 1952" database. This database provides information on the years in which a program started and ended. Consistent with previous work on IMF programs (Dreher and Walter 2010; Jorra 2012; Papi et al. 2015), we define a dummy variable taking 1 if a country had any type of IMF-supported program during the previous five years. We consider a five-year window as reforms may take some time to be implemented under IMF-supported programs. ${ }^{7}$ Appendix Table 16 lists countries that have signed at least one program in our sample together with the number of programs, and Appendix Table 17 reports the list of countries in the present analysis.

Regarding the control variables, our baseline regressions include similar covariates as Jorra (2012). In robustness checks, we will introduce a battery of additional covariates to ensure that the result is not driven by a specific choice of covariates. Our baseline covariates consist of the following: the GDP growth rate, the ratio of reserves-to-imports, the ratio of debt service to exports, the external debt-to-GDP ratio, and a variable capturing parliamentary democracies. Unlike Jorra (2012), we did not include the five-year US treasury constant maturity interest rate since our main regressions include year dummies that capture

\footnotetext{
6 Academic sources include Suter (1992), Beers and Chambers (2006), Tudela et al. (2011), Das et al. (2012), Tweedie et al. (2012), Cruces and Trebesch (2013).

7 In a non-reported regression, we also focus exclusively on agreed Stand-by-Arrangements (SBA) and Extended Fund Facility (EFF) as in Jorra (2012) and find a consistent result.
} 
Table 1. Conditional and unconditional probabilities of a debt crisis in the sample of analysis

\begin{tabular}{llll}
\hline & Conditional & Unconditional & Difference \\
\hline Sovereign debt crisis & 0.027 & 0.035 & 0.008 \\
\hline
\end{tabular}

This table presents the conditional and the unconditional probabilities of the occurrence of a sovereign debt crisis in our sample. The conditional probability is defined as the probability of experiencing a default, conditional on having signed at least an IMF-supported program during the past five years. The unconditional probability is the number of crises divided by the number of non-missing country-year observations

Table 2. Descriptive statistics before weighting

\begin{tabular}{lllrrr}
\hline Variables & {$[1]$} & {$[2]$} & \multicolumn{2}{l}{$[3]=[2]-[1]$} & \\
\cline { 5 - 6 } & $\begin{array}{l}\text { IMF-supported } \\
\text { programs }\end{array}$ & $\begin{array}{l}\text { No IMF-sup- } \\
\text { ported programs }\end{array}$ & Difference & $t$ Test & $p$ Value \\
\hline Real GDP growth $t-1$ & 4.073 & 4.161 & 0.088 & 0.443 & 0.658 \\
Debt service-to-exports $_{t-1}$ & 19.500 & 17.030 & -2.470 & -2.541 & 0.011 \\
Reserves-to-imports $_{t-1}$ & 31.250 & 37.330 & 6.080 & 5.027 & 0.000 \\
External debt-to-GDP $_{t-1}$ & 70.190 & 46.860 & -23.330 & -11.494 & 0.000 \\
Parliamentary democracy & 0.128 & 0.173 & 0.046 & 3.644 & 0.000 \\
Observations & 1652 & 1616 & & &
\end{tabular}

This table presents the pre-weighting sample means of the matching covariates for country-year observations where IMF-supported programs where in place (the treatment group) in column [1] and country-year observations where no IMF-supported programs were in place (the potential control group) in column [2]. Column [3] reports the differences in means between treated and control group, and the corresponding $t$ test statistics and $p$ values

time-specific factors more broadly, including the US treasury interest rate. Consistent with previous findings, we expect the first two variables and the last one to be negatively correlated with the probability of sovereign defaults, while debt service and external debt may be positively correlated. Appendix Table 18 presents the sources and definitions of the data used in this paper.

A first step in assessing the relationship between IMF-supported programs and SDC can be comparing the unconditional and conditional probabilities of SDC occurrence in our sample. In Table 1, the unconditional probability of a sovereign default - the number of crises divided by the number of non-missing country-year observations-is $3.5 \%$ points (pp). However, the conditional probability - the probability of experiencing a debt crisis conditional on having an IMF program during the past five years-is $2.7 \mathrm{pp}$. These correlations suggest that countries with Fund programs with the Fund have approximately 0.8 pp lower probability of experiencing a debt crisis compared to nonprogram countries in our sample. Building on these correlations, we therefore dig deeper into the analysis in the next section. 
Table 3. Descriptive statistics after weighting

\begin{tabular}{lllrrr}
\hline Variables & {$[1]$} & {$[4]$} & \multicolumn{2}{l}{$[5]=[4]-[1]$} & \\
\cline { 5 - 7 } & $\begin{array}{l}\text { IMF-supported } \\
\text { programs }\end{array}$ & $\begin{array}{l}\text { No IMF-sup- } \\
\text { ported programs }\end{array}$ & Difference & $t$ Test & $p$ Value \\
& 4.073 & 4.077 & 0.004 & -0.023 & 0.982 \\
Real GDP growth & & 19.390 & -0.110 & 0.092 & 0.927 \\
Debt service-to-exports $_{t-1}$ & 19.500 & 31.830 & 0.580 & -0.577 & 0.564 \\
Reserves-to-imports $_{t-1}$ & 31.250 & 69.420 & -0.770 & 0.211 & 0.833 \\
External debt-to-GDP $_{t-1}$ & 70.190 & 0.132 & 0.004 & -0.325 & 0.745 \\
Parliamentary democracy & 0.128 & 3268 & & & \\
\hline Observations & 3268 & & & & \\
\hline
\end{tabular}

This table presents the sample means matching covariates after weighting across the treated IMF-supported programs group in column [1] and the synthetic control group obtained from entropy balancing in column [4]. Column [5] shows the differences in means, the $t$ test statistics and the associated $p$ values

Table 4. IMF-supported programs and sovereign debt crises-Baseline results

\begin{tabular}{llllll}
\hline & {$[1]$} & {$[2]$} & {$[3]$} & {$[4]$} & {$[5]$} \\
\hline IMF-supported programs $_{t-1, t-5}$ & $-0.0138^{* * *}$ & $-0.0143^{* * *}$ & $-0.0150^{* * *}$ & $-0.0135^{* * *}$ & $-0.0135^{* *}$ \\
& $(0.0063)$ & $(0.0066)$ & $(0.0067)$ & $(0.0066)$ & $(0.0067)$ \\
Covariates in the second step & No & Yes & Yes & Yes & Yes \\
Year fixed effect in the second step & No & No & Yes & No & Yes \\
Regional fixed effect in the second & No & No & No & Yes & Yes \\
step & & & & & 3182 \\
Observations & 3268 & 3182 & 3182 & 3182 & 3182 \\
\hline
\end{tabular}

This table presents the effect of IMF-supported programs on sovereign debt crises obtained by weighted least squares regressions. The treatment variable is the presence of IMF-supported programs. The outcome variable is the occurrence of a sovereign debt crisis. The control variables include one-year lagged values of real GDP growth, debt service-to-exports, reserves-to-imports, external debt-to-GDP, and parliamentary democracy. Column [1] reports the result without the matching covariates in the second step of the entropy balancing. Column [2] brings the covariates to the regression. Columns [3] and [4] control for year and regional fixed-effects, respectively. Finally, column [5] gathers the covariates, and year and regional fixed-effects into the second step regression. Robust standard errors are in parentheses

$* * * p<0.01, * * p<0.05, * p<0.1$

\section{Baseline Results}

Table 4 presents the impact of IMF-supported programs on SDC using the entropy balancing. Before getting into the treatment effect estimate, let us focus on the performances of the entropy balancing in building a fairly close counterfactual of nonprogram units. Tables 2 and 3 present the sample means of matching covariates before and after weighting used to estimate the impact of IMF-supported programs on SDC. The evidence in Table 2 suggests that countries that have adopted at least one program during the past five years (column [1]) differ from countries that have not (column [2]). Indeed, countries that have signed at least one program have (i) lower real GDP growth-although the difference is not statistically significant, 
(ii) higher debt service-to-GDP, (iii) lower reserves-to-imports, (iv) higher external debt-to-GDP, and (v) lower level of parliamentary democracy, compared to other countries. However, after having created the balanced sample using the covariate moments, the results in Table 3 clearly show no significant differences between the two groups. The lack of differences between the groups strongly demonstrates the effectiveness of the entropy balancing method in building a desired balance.

The main finding is reported in Table 4. Column [1] shows the regression's result without the matching covariates in the second step of the entropy balancing. Column [2] brings the covariates into the regression. Columns [3] and [4] control for year and regional fixed-effects, respectively. Finally, column [5] gathers the covariates as well as year and regional fixed-effects into the regression. Our finding is robust: irrespective of the specifications, the estimated effects of IMF-supported programs on subsequent sovereign defaults are negative and statistically significant. The magnitude of the coefficients varies between 1.3 and $1.5 \mathrm{pp}$. The magnitude of the coefficient of our preferred specification is $1.3 \mathrm{pp}$ in column [5]. Unlike Jorra (2012), our finding suggests that IMF lending programs significantly reduce the likelihood of subsequent sovereign defaults by $1.3 \mathrm{pp}$ in program countries compared to nonprogram countries. This estimate is economically meaningful as it corresponds to about $1 / 3$ of the unconditional probability of experiencing a sovereign default in our sample.

\section{Robustness Checks}

Our previous finding shows that the presence of IMF-supported programs lowers the probability of subsequent sovereign defaults in program countries, compared to nonprogram countries. In the following, we perform a large set of robustness exercises to ensure that this finding is not sensitive to alternative specifications and identification strategies. In performing these robustness checks, we focus our attention on the sign and statistical significance of the principal variable of interest-IMF-supported programs.

\subsection{Alternative Specifications ${ }^{8}$}

We perform alternative specifications as follows. First, we compare our result with Jorra's. To this end, we report Jorra's main regressions that show a positive effect of IMF programs on sovereign debt crises in Table 5. We then present several robustness checks in Tables 6 and 7 to explore the factors that could explain the difference between our paper's finding and Jorra's, using the entropy balancing method. Columns [1]-[5] of Table 6 report the results of the entropy balancing using Jorra's definition of debt crises-defaults on marketable external debt. Columns [6]-[10]

\footnotetext{
${ }^{8}$ In our alternative specifications, we make sure that, after having created the balanced sample using the covariate moments, the results indicate no significant differences between the nonprogram and program groups. The covariate balancing checks are available upon request from the authors.
} 


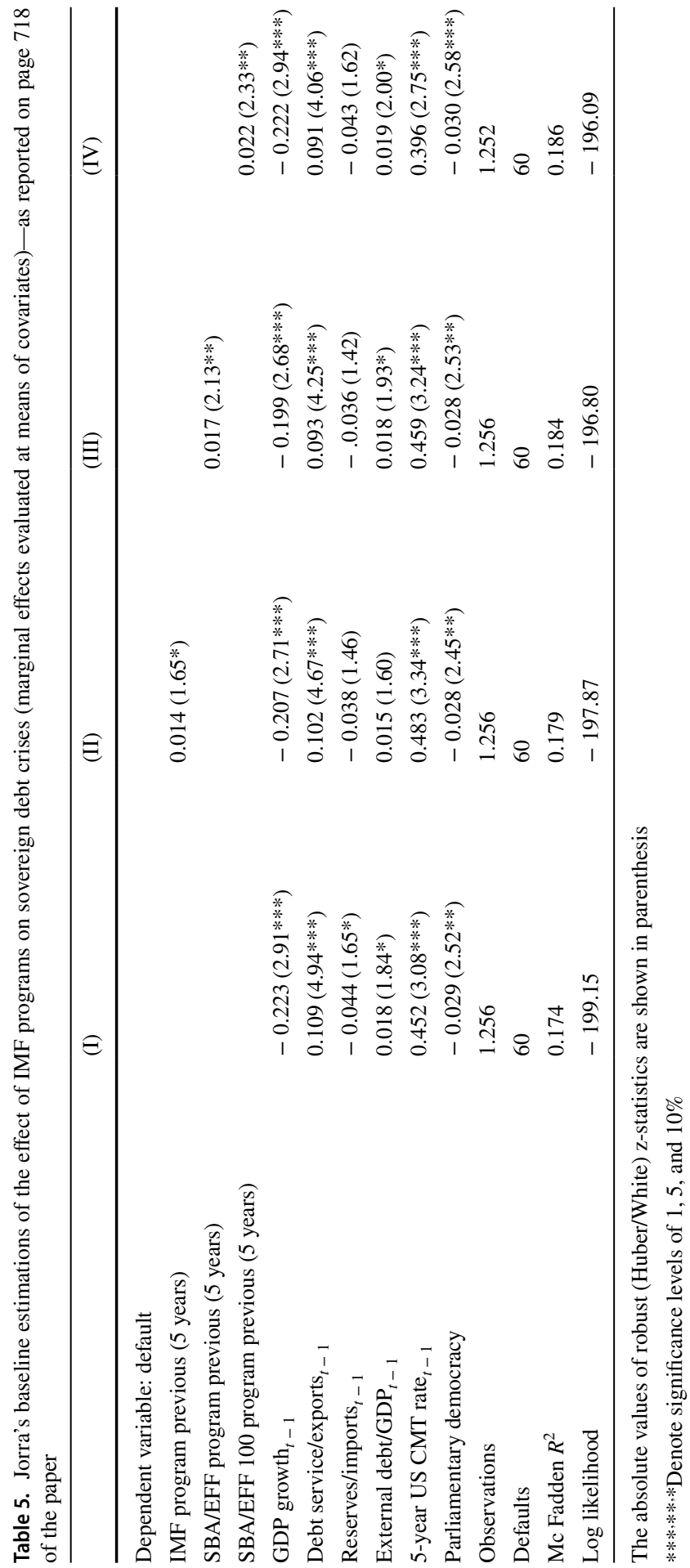




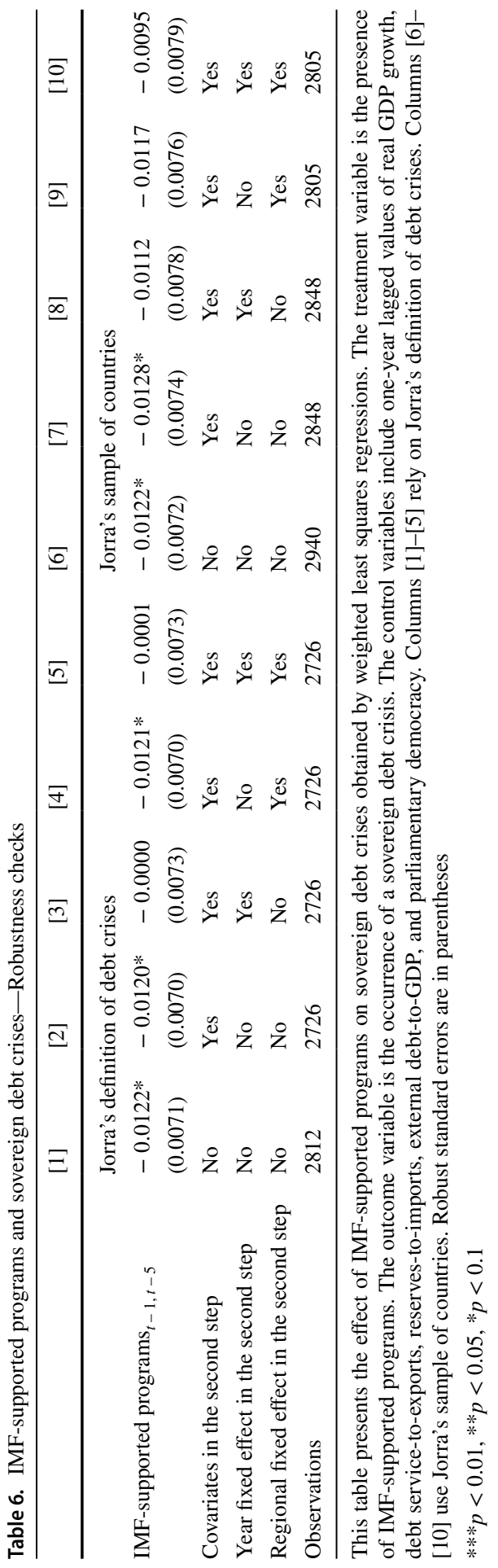

称 


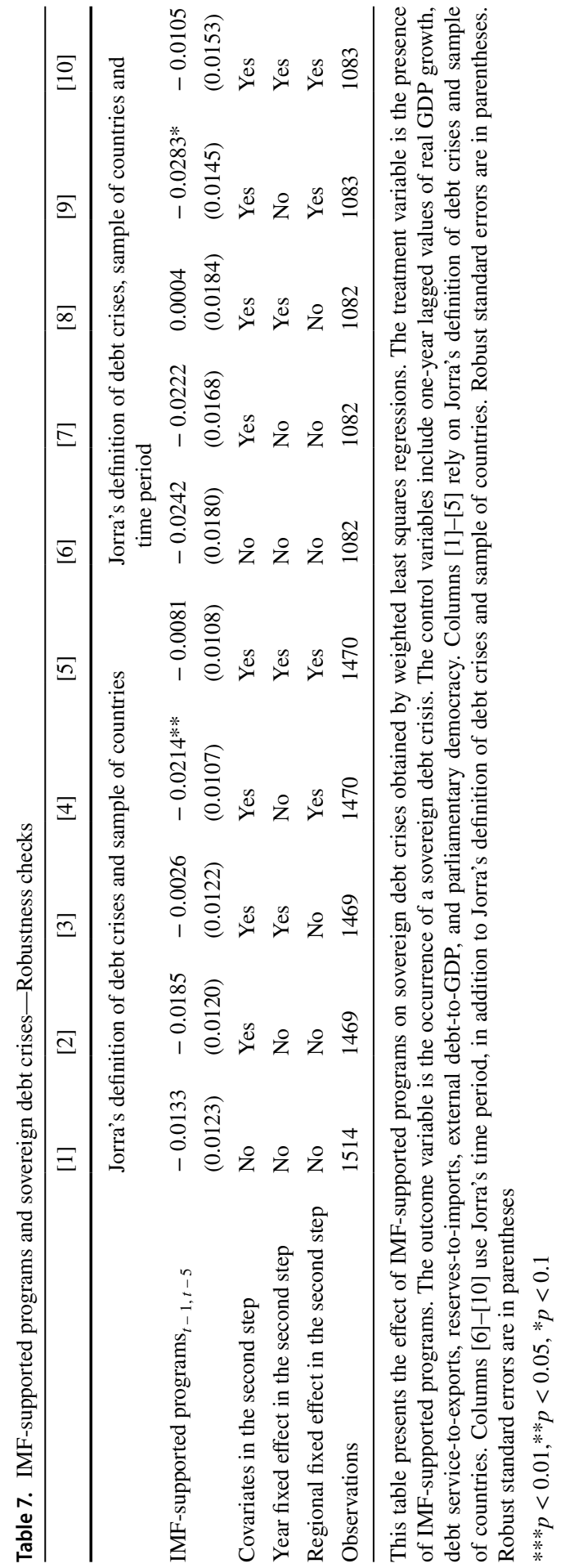


of Table 6 employ Jorra's sample of countries. Columns [1]-[5] of Table 7 combine Jorra's definition of debt crises and sample of countries. Finally, columns [6]-[10] of Table 7 bring in Jorra's period of analysis, in addition to his definition of debt crises and sample of countries. In both tables, we find that, more broadly, the estimated effects are negative but not statistically significant-although some estimates appear slightly statistically significant, the main estimates that control for unobservable factors are not (columns [5] and [10] of both tables). This suggests that when we use Jorra's definition of debt crises, sample of countries and time period-leaving the only difference to be the use of the entropy balancing that properly addresses the selection on unobservable factors and multicollinearity issues-the story is different: IMF programs have a negative but not statistically significant effect on sovereign debt crises. Taken together with Table 4's finding, our results suggest that, in addition to the advantage of the entropy balancing, accounting for the fact that the sovereign debt landscape and the type of IMF programs have changed over time are key factors in explaining the negative estimated effect of IMF programs on default probabilities.

Second, domestic arrears often reflect technical defaults resulting from administrative errors or convenient strategic behaviors between governments and local suppliers. Therefore, we want to know if the result changes when domestic arrears are excluded from our baseline definition of SDC. The corresponding new regressions are reported in columns [1]-[5] of Table 8. Consistent with the previous finding, the estimated coefficients remain negative and statistically significant.

Our third robustness check uses an alternative database of sovereign defaults. Columns [6]-[10] of Table 8 report the regressions using the well-known Laeven and Valencia database on external defaults. While the number of sovereign defaults is relatively low in Laeven and Valencia (38 events compared to 115 events in the CRAG database), interestingly, we find that our conclusion does not change. The estimated effect of the IMF-supported programs dummy is negative, statistically significant, and of comparable magnitude compared to the baseline estimate.

Fourth, the result remains robust in the use of alternative lag structures of IMFsupported programs. Columns [1] and [2] of Table 9 employ more restrictive lag structures and define the treatment variable equal 1 if a country adopted at least one program in the previous 3 and 4 years, respectively. ${ }^{9}$ Columns [3] and [4] opt for more flexible definitions: the treatment variable equal 1 if the country signed one program in the previous 6 and 7 years, respectively. We find that using different lag structures does not affect our main conclusion, since the estimated treatment effect does not change significantly.

Fifth, we look at the potential role of the 2008-10 financial crisis. Column [5] of Table 9 excludes this crisis period from the analysis to isolate its impact. Excluding this crisis period does not affect our main conclusion: the estimated effect of IMFsupported programs is still negative and statistically significant.

\footnotetext{
9 These results and those for the remaining alternative specification checks are based on our preferred specification that controls for the covariates, and year and regional fixed-effects in the second step of the entropy balancing.
} 


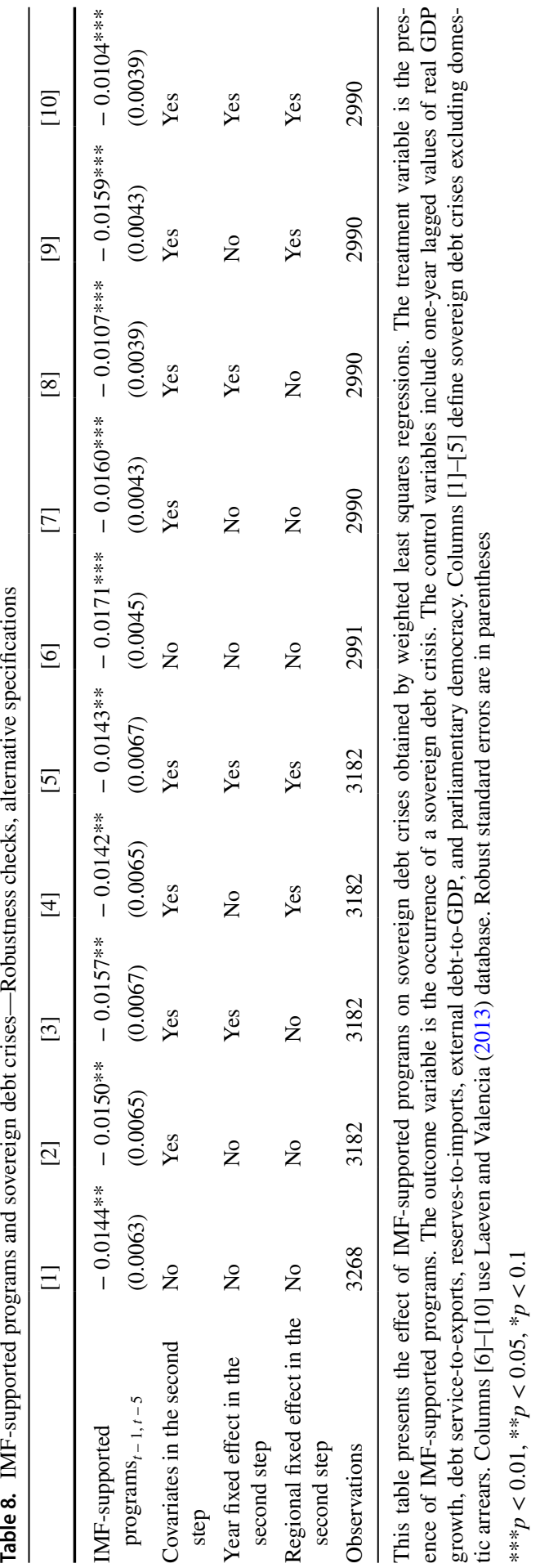




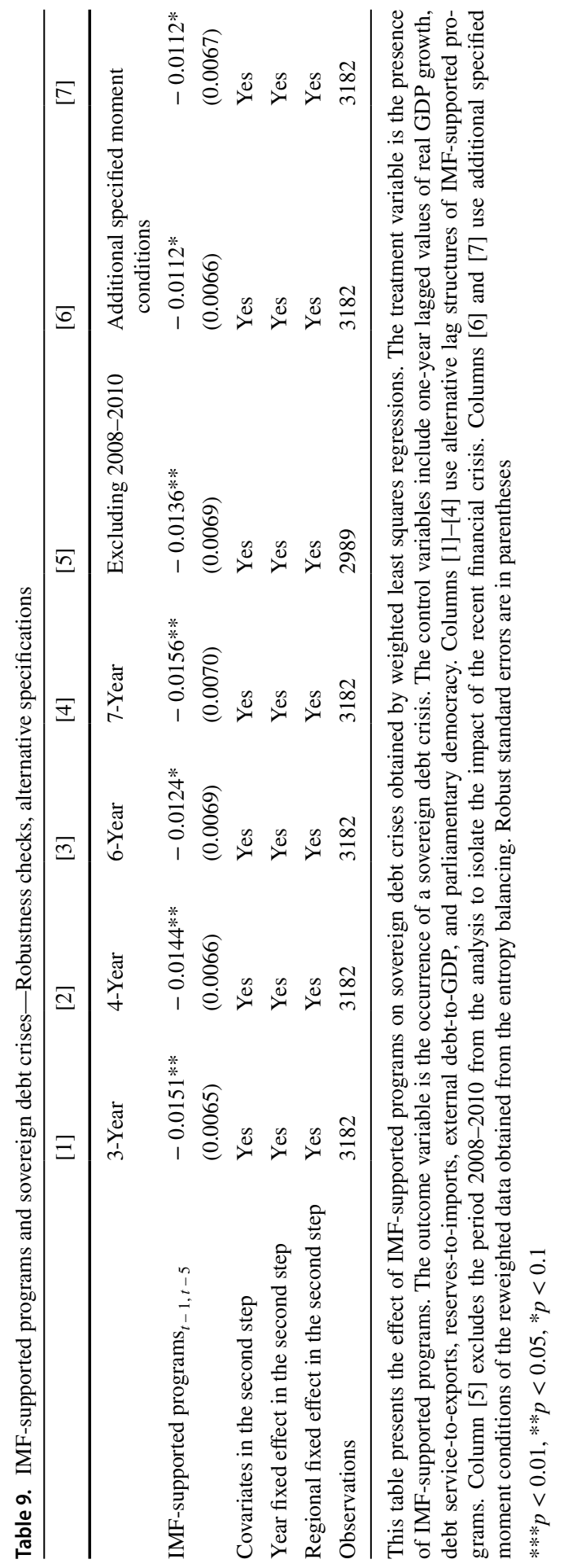

称 
Sixth, we want to know if the result holds for additional specified moment conditions of the entropy balancing's reweighted data. In column [6] of Table 9, the control units' balance constraints are reweighted to include the 1st and the 2nd moments-means and variances. Analogously, in column [7] of Table 9, the reweighted scheme encompasses the control units' 1st, 2nd, and 3rd moments. The estimated effects reported in both columns remain negative and statistically significant, suggesting that using additional moment conditions confirms our previous finding.

The final alternative specification check consists of controlling for a large set of control variables that may affect both countries likelihood of signing IMF programs and experiencing sovereign defaults. The additional covariates, borrow from the related literature, cover various macroeconomic dimensions including the state of the real economy (real GDP per capita), the external sector (trade openness to GDP, current account balance-to-GDP), internal stability (inflation rate), the level of financial development (capital openness index, private credit to GDP, and sovereign CDS market dummy), and macroeconomic volatility (GDP growth volatility, banking crisis dummy, and currency crisis dummy). All these covariates are lagged by one year to overcome reverse causality issues. As reported in Table 10, we find that after controlling for these additional covariates, the main conclusion does not change.

\subsection{Alternative Identification Strategies}

Is the previous result robust to alternative identification strategies? In the following, we provide an answer to this question using an instrumental variable approach as well as conventional matchings.

\subsubsection{Instrumental Variable Approach}

The instrumental variable (IV) approach has been widely used in previous work on IMF-supported programs (Barro and Lee 2005; Eichengreen et al. 2006; Dreher and Walter 2010; Papi et al. 2015). The challenge with this approach obviously consists in identifying the variables that affect the likelihood of program participation but do not affect sovereign defaults other than through the effect on program adoption. We instrument IMF lending using two political variables. First, existing studies show that borrowers that have closer ties with the Fund's major shareholders-proxied by countries' voting behavior at the United Nations General Assembly (UNGA) — are more likely to have successful negotiations and better terms with the IMF (Thacker 1999; Barro and Lee 2005; Dreher and Walter 2010; Papi et al. 2015). Following this literature, we use the UNGA affinity index as our first candidate of instrumental variables for IMF programs. The affinity index measures the fraction of time a country voted in line with the Fund's main shareholders. To ensure that our IV result is not driven by a biased definition of the IMF main shareholders, we consider three groups of main shareholders: the USA, the G5, and the G7. We then compute the average affinity index for each group, using three categories of vote data (approval 


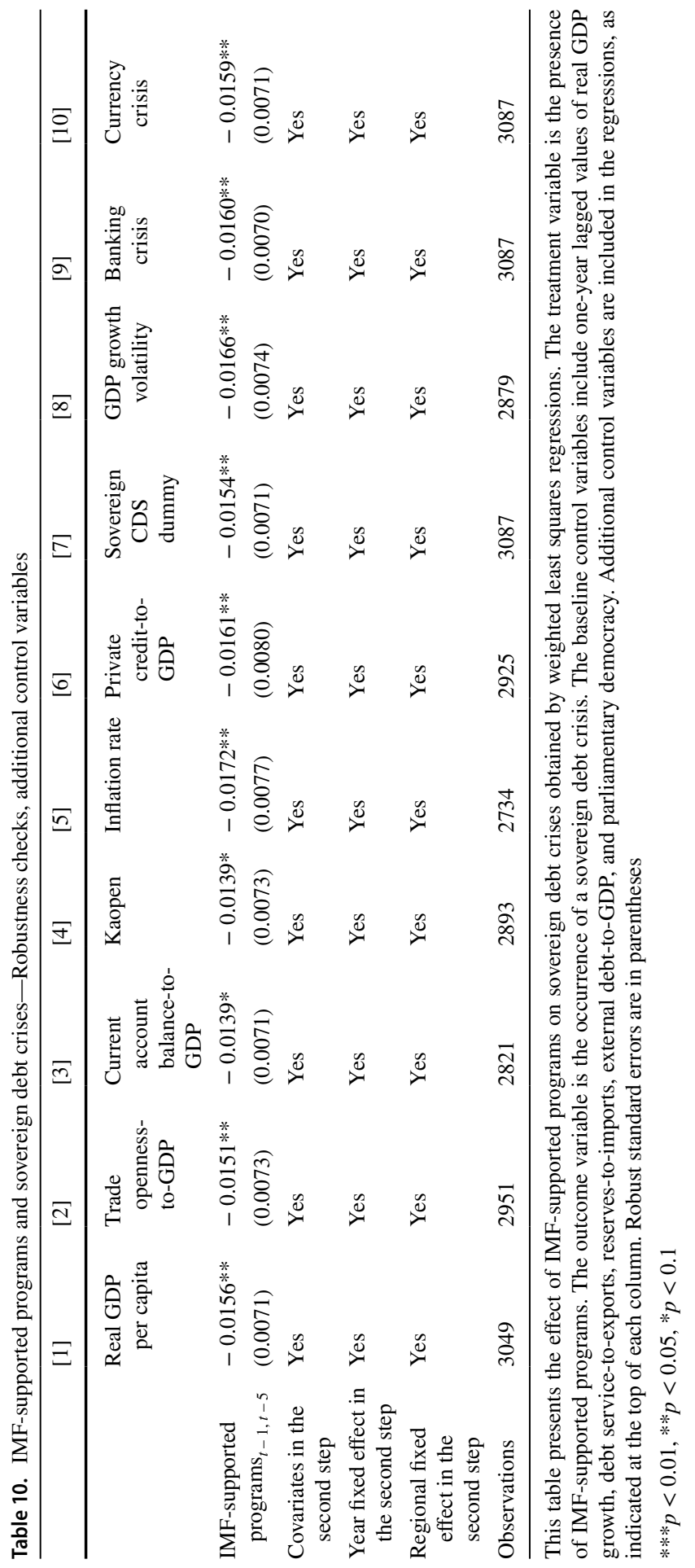

s. 
of an issue, abstention, and disapproval of an issue) and focusing exclusively on important UNGA votes, as declared by the U.S. State Department. In so doing, the UNGA affinity index is a good instrument if it explains IMF programs but is not correlated with sovereign defaults. But a violation of this exclusion restriction may arise when sovereign defaults are endogenous to the IMF main shareholders' behavior: for instance a creditworthiness deterioration arising from the cut of foreign aid. This may arise as the voting behavior at the UNGA has been widely accepted as a reliable indicator of the political motivation of aid (Alesina and Dollar 2000; Alesina and Weber 2002; Gates and Hoeffler 2004; Fink and Redaelli 2011; Dreher and Sturm 2012; Dreher et al. 2015). We overcome this issue by providing estimates that control for foreign aid.

Our second instrument exploits the fact that countries may engage in Fund programs following the introduction of a new administration (Przeworski and Vreeland 2000; Vreeland 2002; Harrigan et al. 2006; Papi et al. 2015). Consequently, we use a dummy variable identifying executive election years as a second instrumental variable. The underlying philosophy is that governments may be more willing to seek programs with the Fund at the beginning of their terms in office. This may be part of governments political game in order to reduce the potential adverse effect of IMF's conditionality on their chances of getting reelected on the eve of elections.

Finally, given that we are interested in the impact of IMF presence in the past 5 years $(t-1, t-5)$, we follow Papi et al. (2015) and build the UNGA affinity score also as the average over six- to ten-year period $(t-6, t-10)$. In the same vein, the second instrument - executive election — takes the value of 1 if the country experienced an executive election in the period $(t-6, t-10)$.

The result of the IV approach estimated using a probit model is reported in Tables 11 and 12. Table 11 uses the UNGA affinity score and executive election as instruments. Columns [1]-[6] of Table 11 present the probit regressions using the conditional maximum likelihood estimator, while columns [7]-[12] of Table 11 use the Newey two-step estimator. For each estimator, we report two regressions for the different group of shareholders (G7, G5, and USA), without and including regional fixed effects. Table 12 replicates the previous table's regressions but controlling for foreign aid. ${ }^{10}$

Before we examine the result of our main variable of interest-IMF-supported program-let us focus on the relevance and validity of the instruments. In each column of Tables 11 and 12, we report the first stage IV results- that are the estimated parameters of the instruments and the F-tests. Two interesting points emerged. First, the coefficients of our instruments are statistically significant at the $1 \%$ level with the signs consistent with the theory. Consistent with the above discussions, countries that vote in line with the IMF's main shareholders at the UNGA and those that

\footnotetext{
${ }_{10}$ We do prefer controlling for total foreign aid since the decision to vote or not to vote in line with the USA, the G5, or the G7-knowing that these countries might adjust their development aid consequently-may not be independent from the expected change of behavior of other donors. However, in unreported regression, we also control for aid from the USA, the G5, or the G7 and find the results consistent.
} 


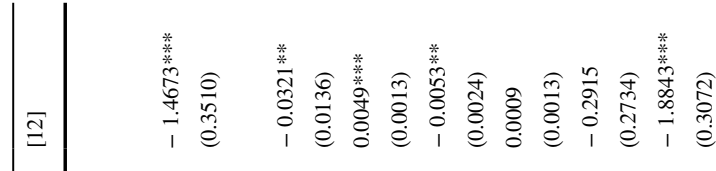

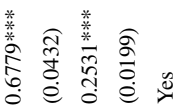

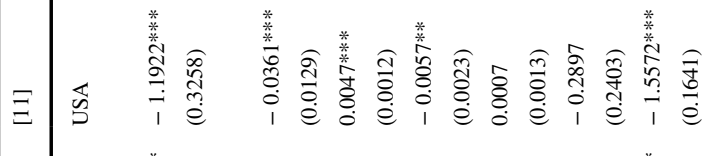

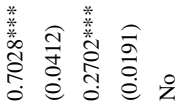

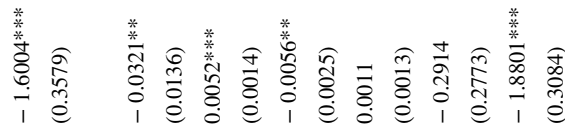

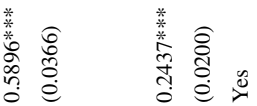

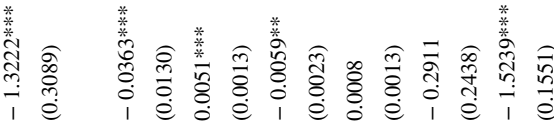

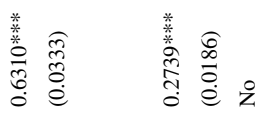

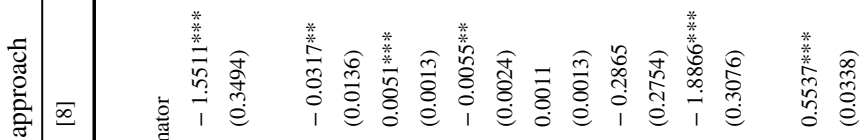

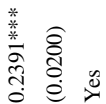

苟

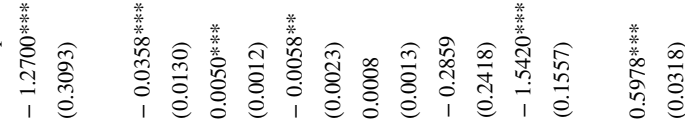

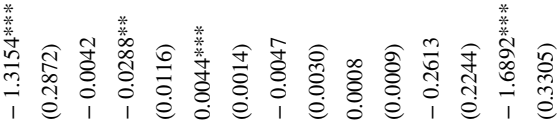

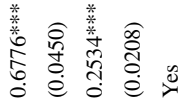

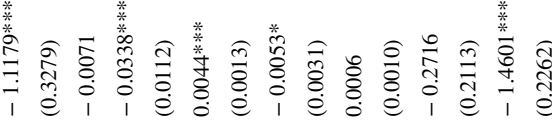

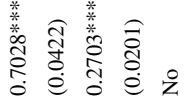

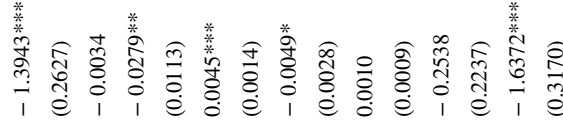

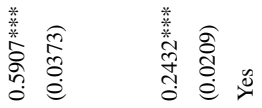

E

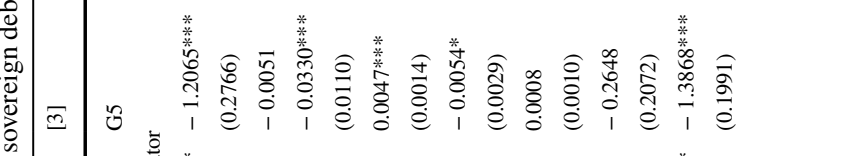

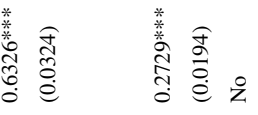

刍

है

$\overline{5}$

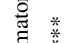

蜜

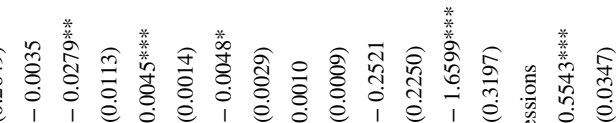

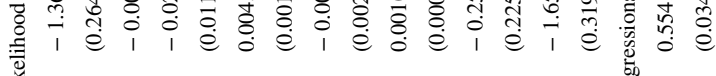

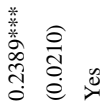

总

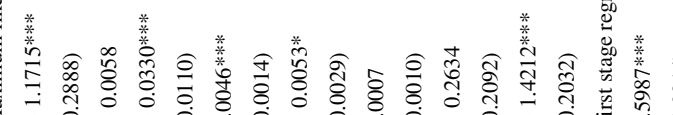

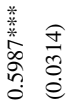

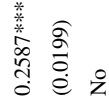

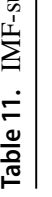

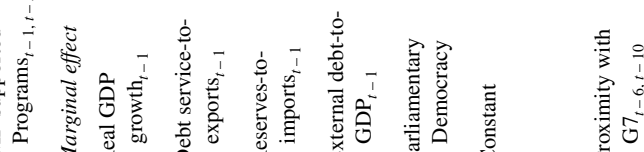

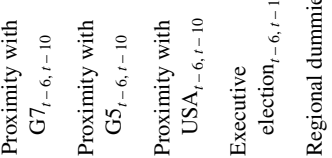

站 


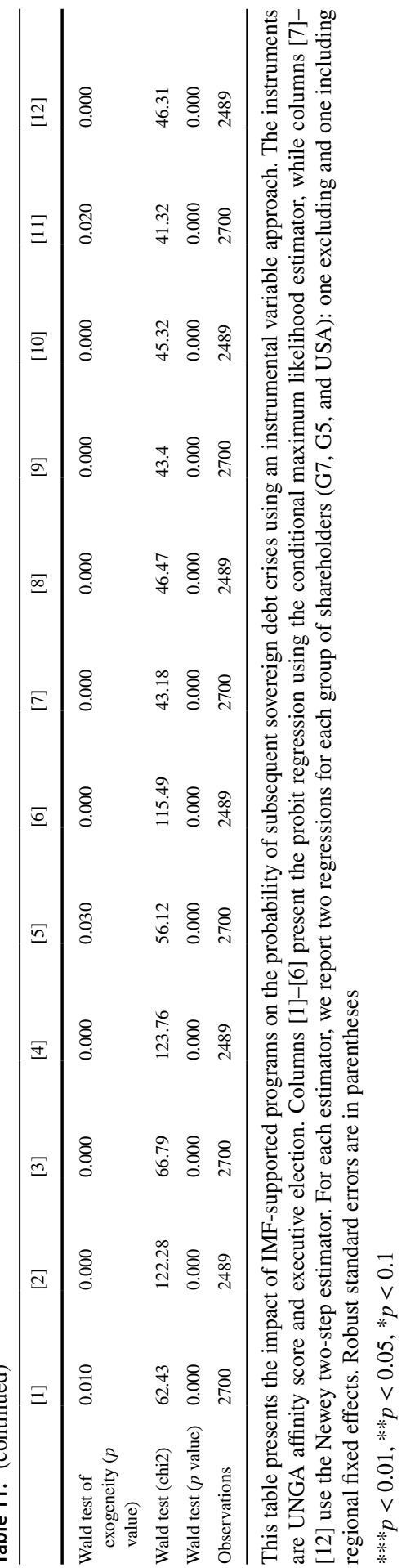




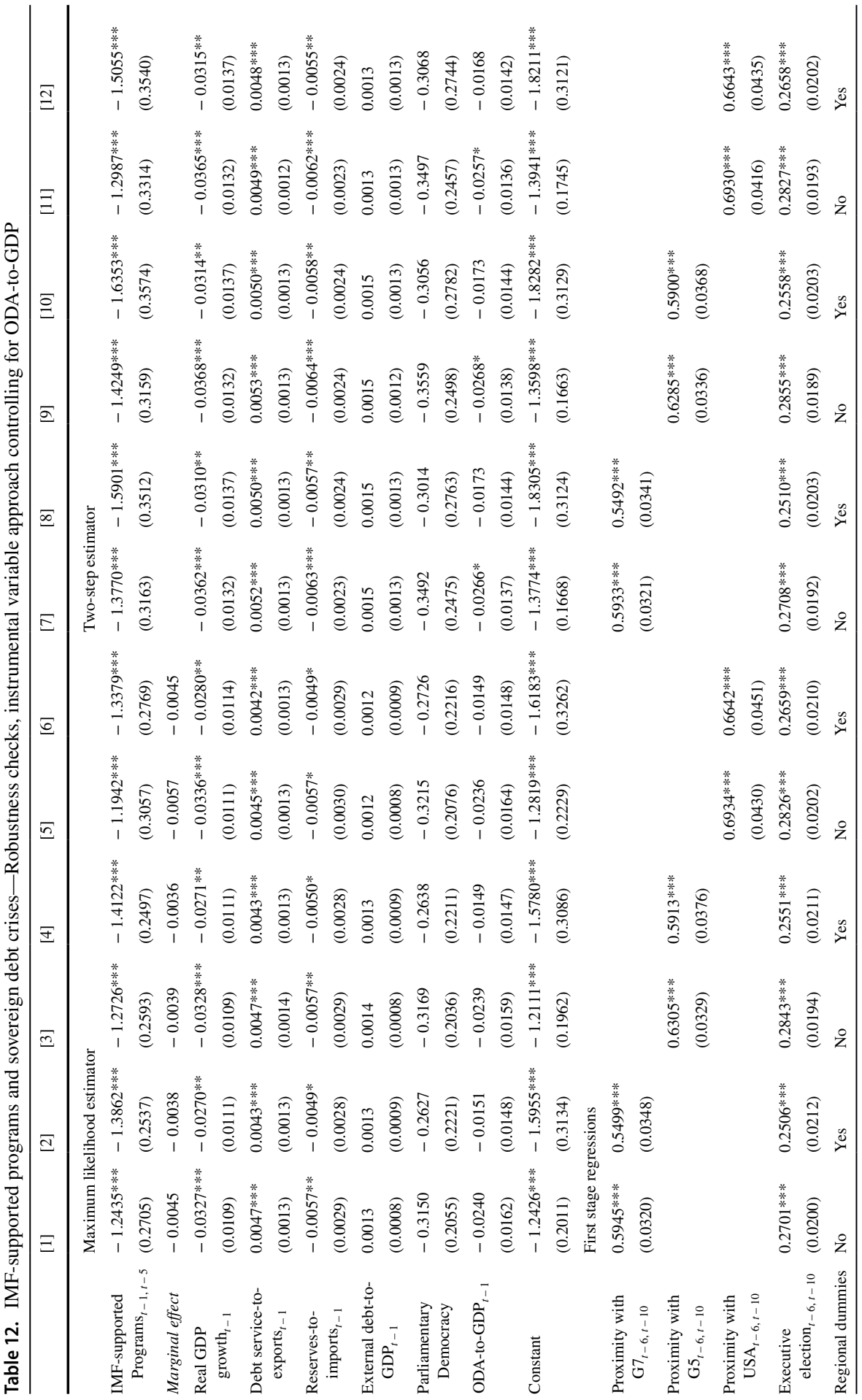

站。 


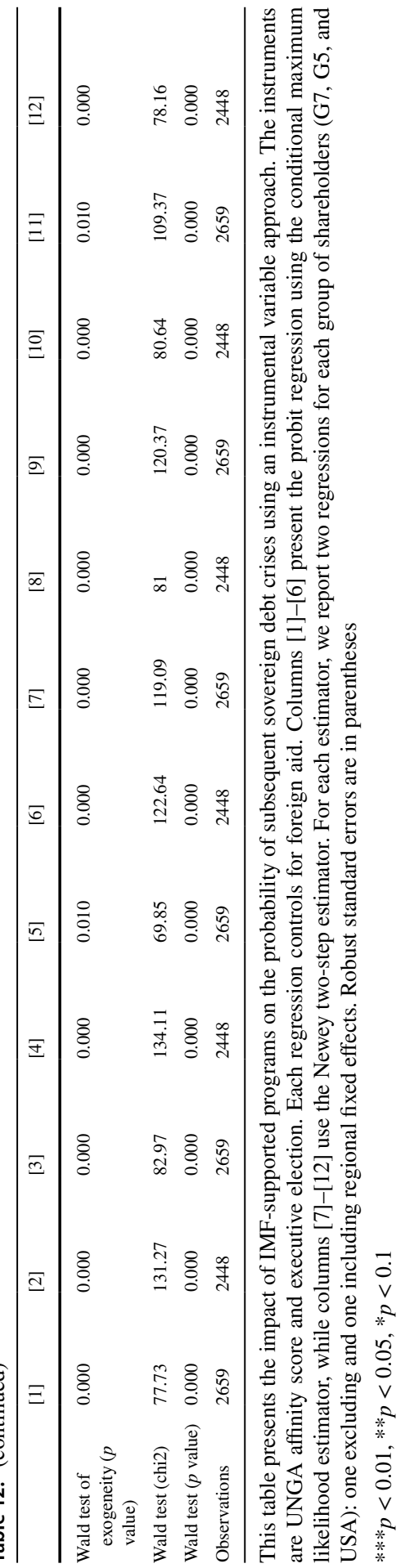


had election in the previous years are more likely to sign a program with the Fund. Second, the F-tests of the first stage regressions are higher than 10, with respect to the golden rule of Staiger and Stock (1997). These two facts confirm that our instruments are relevant. In addition, each column reports the Hansen tests for overidentification restrictions. Yet, the $\mathrm{p}$ values of the Hansen tests are larger than conventional levels, suggesting that the overidentification restrictions are not violated. We can therefore conclude that our instruments for IMF lending are relevant and valid. We then move to the main finding.

In Tables 11 and 12, the coefficients of IMF-supported programs are negative and statistically significant, even if their magnitudes are somewhat smaller compared to the entropy balancing's estimates. The IV results confirm the entropy balancing finding that IMF lending programs statistically and economically reduce the probability of subsequent sovereign defaults.

Arguably, the marginal effects of the estimates based on the regression analyses are smaller compared to the entropy balancing approach. This is because in the regression-based approach, a restriction regarding the functional form of the empirical model is imposed (Neuenkirch and Neumeier 2016). However, the treatment effects estimates based on entropy balancing do not suffer from multicollinearity, as the reweighting scheme orthogonalizes the covariates with respect to the treatment indicator, whereas panel regression-based estimates are somewhat prone to multicollinearity.

\subsubsection{Conventional Matchings}

The negative impact of IMF lending programs on the probability of subsequent sovereign defaults is also confirmed using two different methods of conventional matching: propensity score matching (PSM) and bias-corrected matching (BCM). Both approaches consist of comparing program observations with counterfactual nonprogram observations that have similar likelihood of having programs. Under both approaches, the probability of signing a program is estimated in a first step for each country-year observation based on a vector of observable variables. The treatment effect of IMF-supported programs is then computed in a second step using the propensity scores of program adoption estimated and different varieties of matching algorithms. Following Lin and Ye (2007), and Balima et al. (2017), we implement the PSM using these matching algorithms: the $N$-nearest neighbor (with $N=1,2,3$ ), the radius matching (with a radius of $0.005,0.01$ and 0.05 ), the kernel matching, the local linear matching, and the stratification matching. ${ }^{11}$ However, the BCM differs from the PSM as it relies on a regression function estimated only on the nonprogram

\footnotetext{
11 The nearest neighbor matches a program country observation with the $\mathrm{N}$ nearest neighbor nonprogram country observations using the estimated probability. The radius matching compares program and nonprogram observations using a threshold metric of distance. The kernel matching uses an inversed weight to match program and nonprogram units, while the local linear approach follows the kernel matching but does include a linear term in the weighting function. Finally, the stratification matching uses several strata to increase the quality of the comparison and to estimate the treatment effect. For a discussion between these varieties of PSM, see Caliendo and Kopeinig (2008).
} 


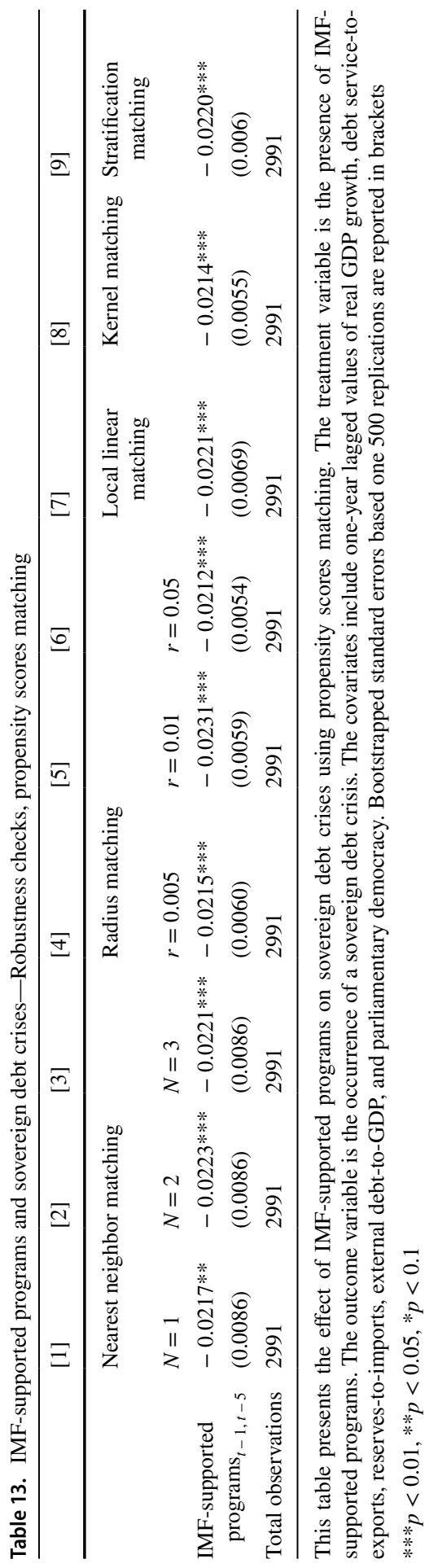




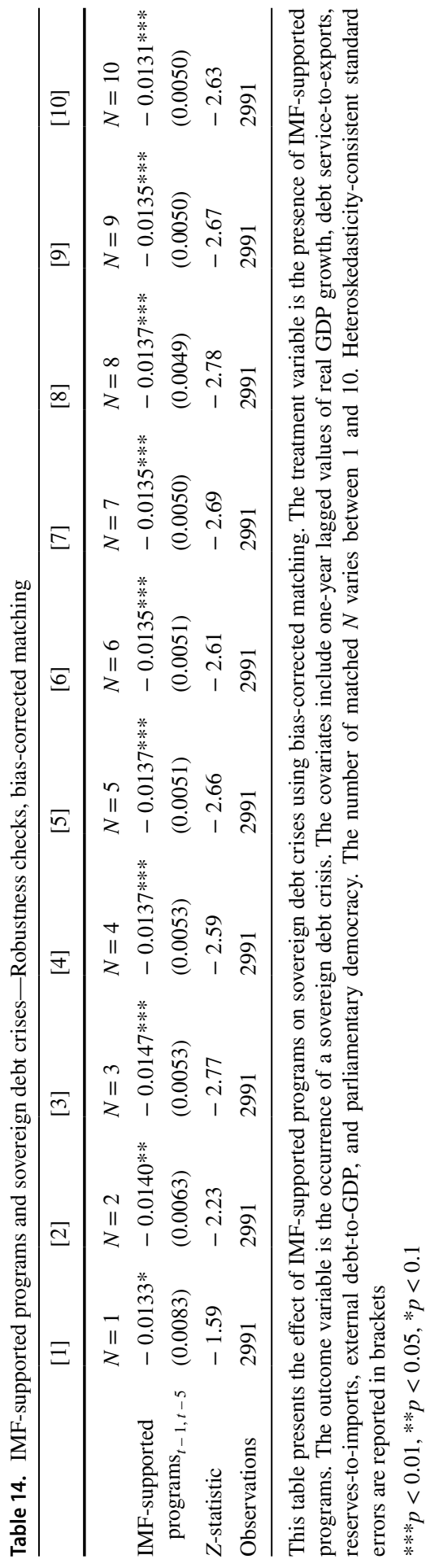

s. 
group to predict the potential outcome (see Abadie and Imbens (2006) for more discussions). In implementing the BCM, we consider the number of matched, $n$ varying between 1 and 10 .

The PSM and the BCM's results are reported in Tables 13 and 14, respectively. The findings confirm the negative impact of IMF lending programs on the likelihood of subsequent defaults. Indeed, the estimated treatment effects are negative and statistically significant in both Tables. However, the average magnitude of the estimates in both cases is somewhat higher than the 1.3 pp. estimate of the entropy balancing.

\section{Potential Explanations}

This section aims to shed light on the mechanisms behind the results. In particular, we test the relevance of three transmission channels discussed in the introduction of the paper: (i) the liquidity provision channel and catalytic role, (ii) the role of the government adjustment effort, and (iii) the role of conditionality. As pointed out by a Referee, a sovereign default, in the end, is a government's decision. But the literature on countries' decisions to default supports the idea that, in addition to debtor country shocks (both economic and political), defaults are influenced by the behavior of creditors and international capital markets (see Aguiar and Gopinath 2006; Tomz and Wright 2007; Levy-Yeyati and Panizza 2011; Reinhart and Rogoff 2014) and "over-borrowing" (IMF 2003; Panizza et al. 2009; Reinhart and Rogoff 2011). Consequently, exploring the transmission channels could help understand the macroeconomic factors behind the estimated negative effect of IMF lending, beyond a government's political consideration of defaulting.

We access the liquidity provision channel and catalytic role through annual changes in sovereign credit rating provided by notations agencies, using data from the three main international credit rating agencies (Standard and Poor's, Moody's, and Fitch). ${ }^{12}$ Existent empirical evidence suggests that a country's credit rating is an important determinant of its international capital market access and the terms of that access (Reinhart 2002; Kaminsky and Schmukler 2002; Gande and Parsley 2005; Pukthuanthong-Le et al. 2007). If IMF-supported programs help solve liquidity shortages and restore confidence, this might also result in an improvement in the borrowing country's credit rating. ${ }^{13}$

Finally, the government adjustment effort and the conditionality channels are conjointly tested by looking at the behavior of government debt-to-GDP and fiscal balance-to-GDP. We believe that government debt or fiscal balance may be a good proxy for measuring the borrowing government's effort and the role of conditionalities for at least two reasons. On the one hand, they are the main fiscal policy

\footnotetext{
12 Following Sy (2002), we use a linear transformation to convert ratings into a discrete variable. Appendix Table 19 details the numerical transformation.

13 We do opt to use credit rating rather than bond yields since data on the latter is not available for a large majority of countries in our sample. By using annual changes in sovereign credit rating, a negative change means a rating downgrade while a positive change reflects a rating upgrade.
} 
Table 15. Transmission channels

\begin{tabular}{llll}
\hline & {$[1]$} & {$[2]$} & {$[3]$} \\
\hline & $\begin{array}{l}\text { Change in } \\
\text { sovereign credit } \\
\text { rating }\end{array}$ & $\begin{array}{c}\text { Government } \\
\text { debt-to- } \\
\text { GDP }\end{array}$ & $\begin{array}{c}\text { Fiscal } \\
\text { balance- } \\
\text { to-GDP }\end{array}$ \\
$\begin{array}{l}\text { Treated group } \\
\text { before an IMF- } \\
\begin{array}{l}\text { supported } \\
\text { program }\end{array}\end{array}$ & -0.06 & 63.93 & -2.96 \\
$\begin{array}{l}\text { during an IMF- } \\
\text { supported } \\
\text { program }\end{array}$ & 0.04 & 58.43 & -2.46 \\
$\begin{array}{l}\text { Control group } \\
\text { pont-5 }\end{array}$ & -0.01 & & -2.70 \\
\hline
\end{tabular}

This table presents the transmission channels of the effect of IMFsupported programs on the probability of subsequent sovereign debt crises

variables in the short and the long run. On the other hand, changes in these two outcomes may directly capture IMF conditionalities on fiscal targets as Fund programs usually include fiscal measures. ${ }^{14}$

We assess these transmission channels following Neuenkirch and Neumeier (2016). In particular, we compute the mean of the above transmission channel variables for (a) the program group observations with at least one program during the past five years, (b) the program group focusing exclusively on observations for which no program has been implemented during the past five years, and (c) the synthetic control group obtained via entropy balancing. The results reported in Table 15 indicate on the one hand that the synthetic control group computed from our entropy balancing differs from the program group before program implementation. Indeed, the former is characterized by a rating downgrade as shown by the negative variation in credit rating ( -0.06 notch vs. -0.01 notch), a higher debt-to-GDP ratio $(63.9 \%$ vs. $59.8 \%)$, and a lower fiscal balance-to-GDP (-3.0\% vs. $-2.7 \%)$. On the other hand, the implementation of IMF-supported programs has been accompanied by a significant decrease in the above outcomes. The change in sovereign credit rating turns from a downgrade ( -0.06 notch) to an upgrade $(0.04$ notch), and the difference is statistically significant $(t=-1.78$; $p$ value $=0.07)$. Regarding debt-toGDP, the program group moves from $63.9 \%$ prior to the program implementation, to $58.4 \%$ during the treatment period, and the difference is also statistically significant $(t=1.99 ; p$ value $=0.04)$. Finally, a similar picture emerges from the fiscal balance, which improves from $-2.96 \%$ before the program to $-2.45 \%$ during the program, the difference being statistically significant $(t=-1.87, p$ value $=0.06)$. In addition, Table 15 also points out that the treatment group experiences a more favorable change in sovereign credit rating and lower debt and fiscal deficit ratios during the

\footnotetext{
14 By using credit ratings, government debt, and fiscal balance, we make the distinction between domestic channels (debt and fiscal balance), and international capital market channels (credit ratings).
} 
treatment period compared to the synthetic control group. These findings suggest that the improvements in sovereign credit rating, debt, and fiscal deficit are channels through which IMF-supported programs decrease the probability of subsequent debt crises in program countries, compared to nonprogram countries.

\section{Conclusion}

In this paper, we analyze the role of bailouts in mitigating the likelihood of subsequent sovereign defaults in developing countries, taking IMF-supported programs as an example. We contribute to the literature on the impacts of bailouts in several areas, including (i) drawing upon a large sample of 106 developing countries, (ii) using a comprehensive database on defaulted government debt, and (iii) properly taking into account the endogeneity of the IMF's presence in a country.

Our result indicates that IMF-supported programs significantly reduce the likelihood of subsequent sovereign debt crises by about $1.3 \%$ points. We provide evidence that this finding is particularly robust to different specifications as well as the use of alternative identification strategies, including an instrumental variable approach and conventional matchings. Moreover, we provide suggestive evidence that (i) the catalytic role and the liquidity provision channel, (ii) the role of government's adjustment effort, and (iii) the conditionality channel may be at work. In particular, we find that a country that signed a program with the Fund experiences a slight improvement in its sovereign credit rating and a decrease in both government debt-to-GDP and fiscal deficit-to-GDP during the program period compared to the period before. Our results are in line with the theoretical model of Corsetti et al. (2006) that shows that lending support not only has an impact on the likelihood and the possible incidence of a crisis, but also prompts the borrowing government to implement desirable policies and reforms.

Our results have some policy implications. Although the adoption of an IMFsupported program can be perceived as having a short-term political cost related to fiscal consolidation, the empirical results of this paper show that IMF interventions yield long-term benefits by helping avoid the costs of sovereign default-such as reputational costs, international trade exclusion costs, costs to the domestic economy through the financial system, and political costs to the authorities-mentioned in the literature (Borensztein and Panizza 2009).

To conclude, while our paper provides suggestive transmission channels, future research could further disentangle the effects of these different channels. For instance, it would be interesting to assess how different types of IMF-supported programs compare in their stabilization role and also study how programs that involve IMF disbursements compare to those that require only IMF advice. 


\section{Appendix}

See appendix Tables 16, 17, 18, and 19. See appendix references (Bailey et al. 2015; Chinn and Ito 2006; Cruz et al. 2016).

Table 16. List of countries having signed at least an IMF-supported program during the sample period

\begin{tabular}{|c|c|c|c|c|}
\hline Country & Country & Country & Country & Country \\
\hline Afghanistan & Colombia & Haiti & Mongolia & $\begin{array}{l}\text { St. Vincent and } \\
\text { the Gren- } \\
\text { adines }\end{array}$ \\
\hline Albania & Comoros & Honduras & Morocco & Sudan \\
\hline Algeria & Congo, Rep. & India & Mozambique & Tajikistan \\
\hline Angola & Costa Rica & Indonesia & Nepal & Tanzania \\
\hline Armenia & Djibouti & Jamaica & Nicaragua & Thailand \\
\hline Azerbaijan & Dominica & Jordan & Nigeria & Tunisia \\
\hline Bangladesh & Dominican Republic & Kazakhstan & Pakistan & Turkey \\
\hline Belarus & Ecuador & Kenya & Panama & Uganda \\
\hline Belize & Egypt, Arab Rep. & Kyrgyz Republic & Papua New Guinea & Ukraine \\
\hline Bolivia & El Salvador & Lao PDR & Paraguay & Vietnam \\
\hline $\begin{array}{l}\text { Bosnia and Herze- } \\
\text { govina }\end{array}$ & Ethiopia & Lesotho & Peru & Yemen, Rep. \\
\hline Brazil & Fiji & Liberia & Philippines & Zambia \\
\hline Bulgaria & Gabon & Macedonia & Rwanda & Zimbabwe \\
\hline Burundi & Gambia & Madagascar & Samoa & \\
\hline Cabo Verde & Georgia & Malawi & $\begin{array}{l}\text { Sao Tome and } \\
\text { Principe }\end{array}$ & \\
\hline Cambodia & Ghana & Maldives & Serbia & \\
\hline Cameroon & Grenada & Mauritania & Sierra Leone & \\
\hline $\begin{array}{l}\text { Central African } \\
\text { Republic }\end{array}$ & Guatemala & Mauritius & Solomon Islands & \\
\hline Chad & Guinea & Mexico & South Africa & \\
\hline China & Guyana & Moldova & Sri Lanka & \\
\hline
\end{tabular}




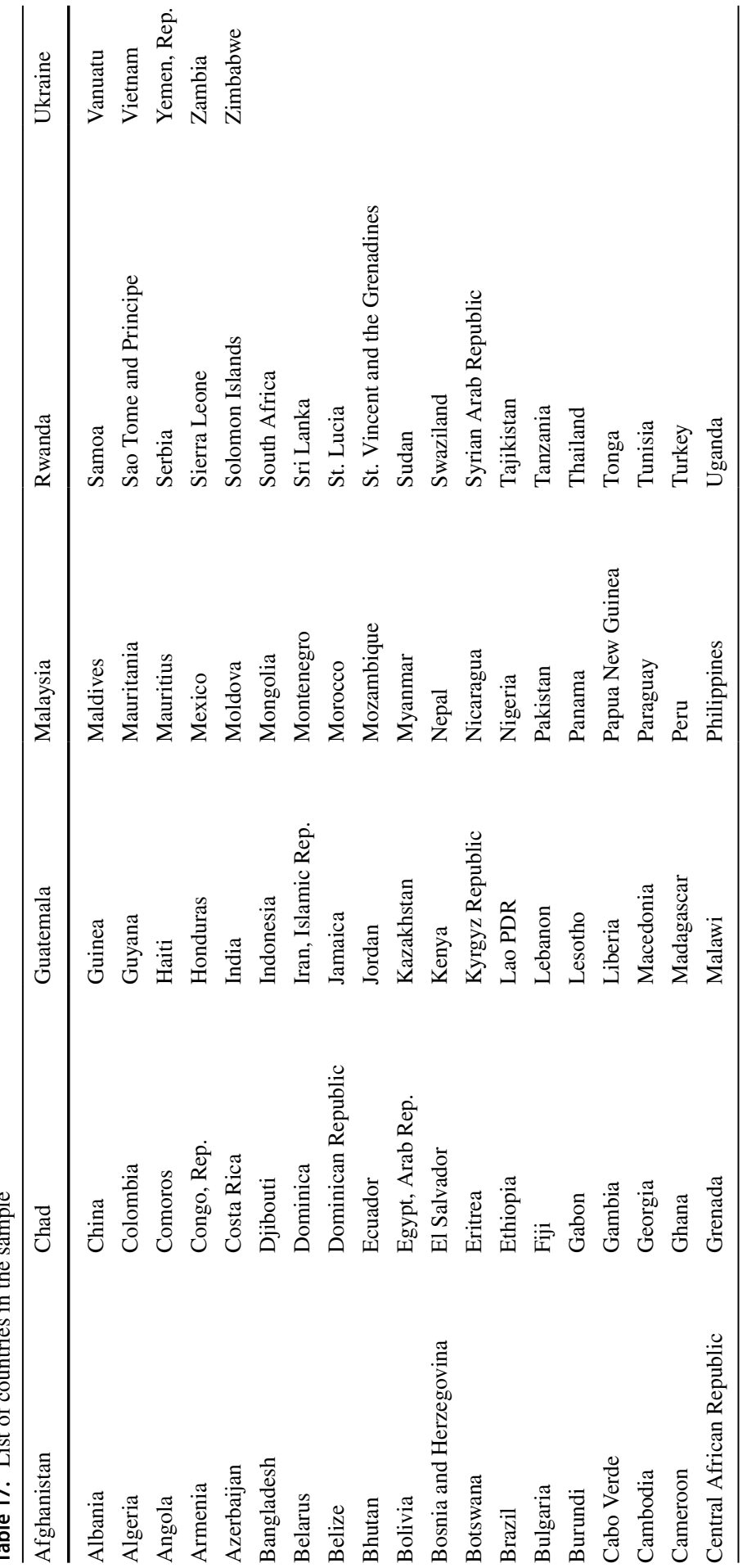




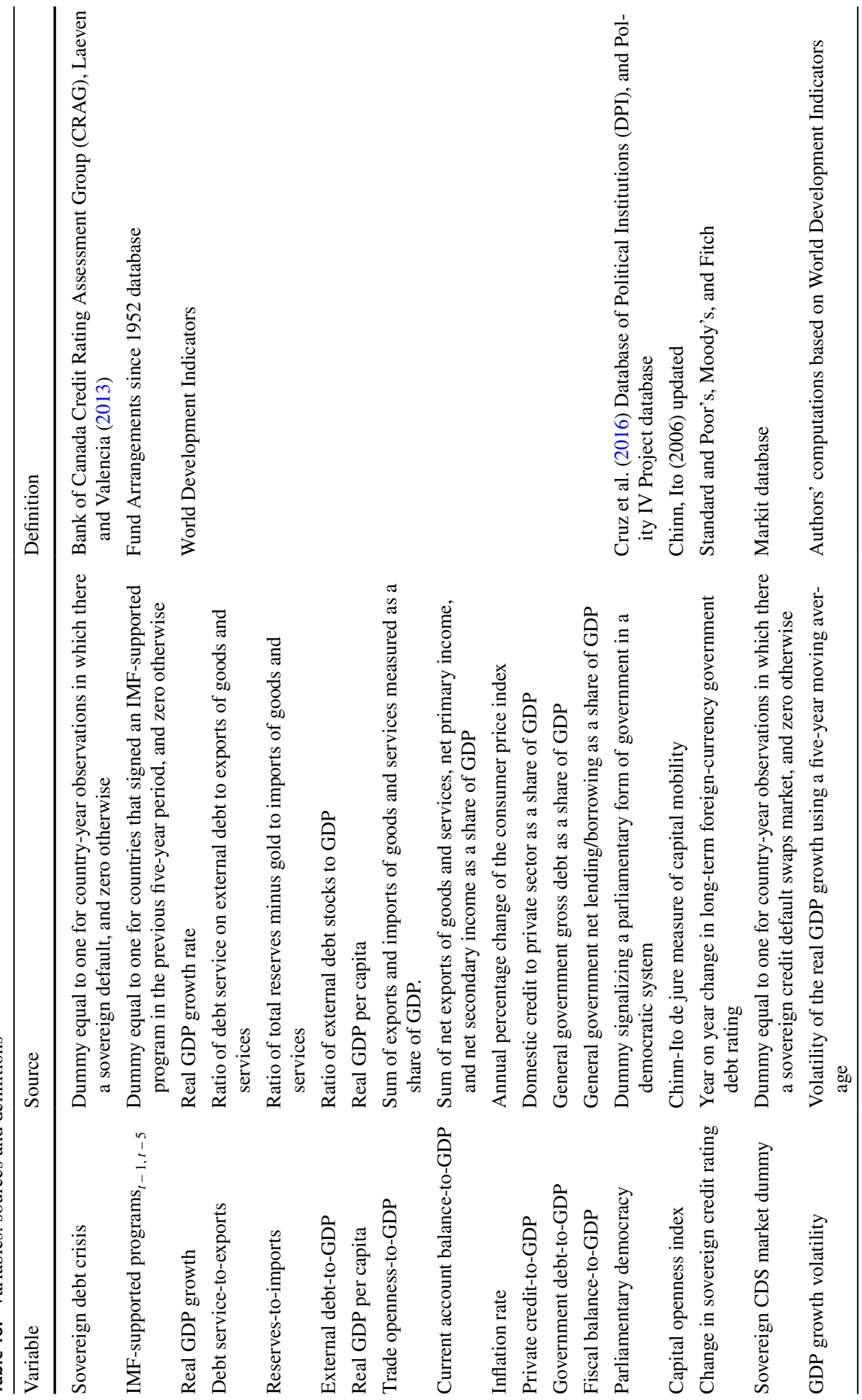

我造 


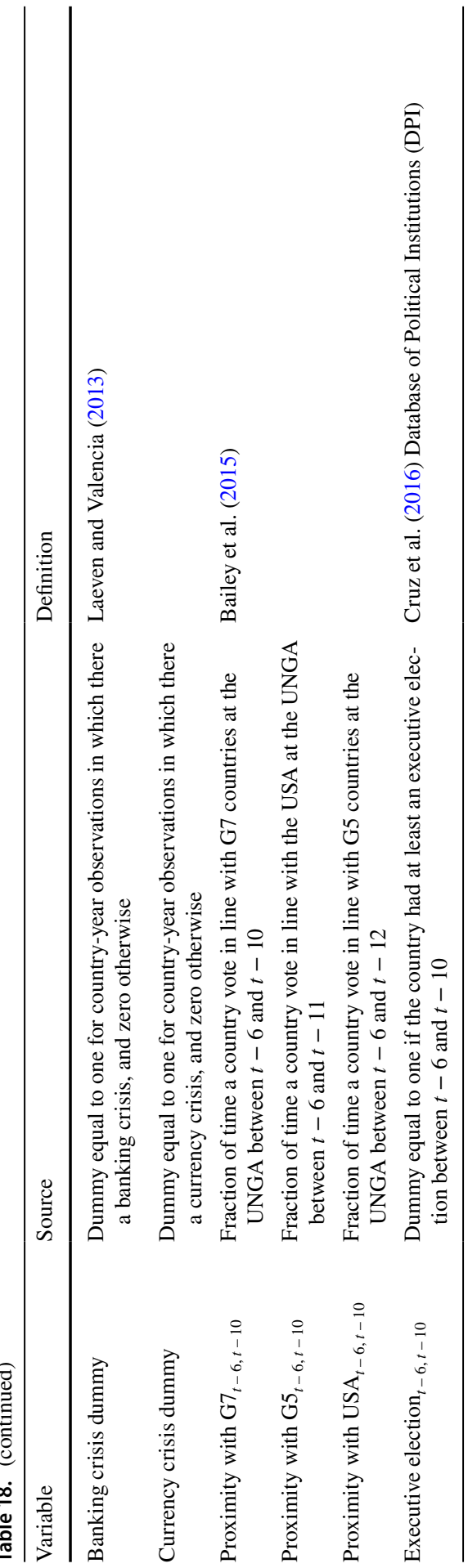


Table 19. Linear conversion of Standard and Poor's, Moody's and Fitch ratings

\begin{tabular}{|c|c|c|c|c|c|}
\hline Rating grade & Risk level & $\begin{array}{l}\text { Standard } \\
\text { and Poor's }\end{array}$ & Moody's & Fitch ratings & $\begin{array}{l}\text { Linear } \\
\text { con- } \\
\text { version }\end{array}$ \\
\hline \multirow[t]{10}{*}{ Investment grade } & Highest quality & AAA & Aaa & AAA & 21 \\
\hline & \multirow[t]{3}{*}{ High quality } & $\mathrm{AA}+$ & Aa1 & $\mathrm{AA}+$ & 20 \\
\hline & & AA & $\mathrm{Aa} 2$ & AA & 19 \\
\hline & & $\mathrm{AA}-$ & Aa3 & $\mathrm{AA}-$ & 18 \\
\hline & \multirow[t]{3}{*}{ Strong payment capacity } & $A+$ & A1 & $\mathrm{A}+$ & 17 \\
\hline & & A & A2 & A & 16 \\
\hline & & $A-$ & A3 & $\mathrm{A}-$ & 15 \\
\hline & \multirow[t]{3}{*}{ Adequate payment capacity } & $\mathrm{BBB}+$ & Baa1 & $\mathrm{BBB}+$ & 14 \\
\hline & & $\mathrm{BBB}$ & $\mathrm{Baa} 2$ & $\mathrm{BBB}$ & 13 \\
\hline & & $\mathrm{BBB}-$ & Baa3 & $\mathrm{BBB}-$ & 12 \\
\hline \multirow[t]{15}{*}{ Speculative grade } & \multirow{3}{*}{$\begin{array}{l}\text { Likely to fulfill obligations, ongoing } \\
\text { uncertainly }\end{array}$} & $\mathrm{BB}+$ & Ba1 & $\mathrm{BB}+$ & 11 \\
\hline & & $\mathrm{BB}$ & $\mathrm{Ba} 2$ & $\mathrm{BB}$ & 10 \\
\hline & & $\mathrm{BB}-$ & $\mathrm{Ba3}$ & $\mathrm{BB}-$ & 9 \\
\hline & \multirow[t]{3}{*}{ High credit risk } & $\mathrm{B}+$ & B1 & $\mathrm{B}+$ & 8 \\
\hline & & B & B2 & B & 7 \\
\hline & & B- & B3 & B- & 6 \\
\hline & \multirow{8}{*}{$\begin{array}{l}\text { Very high credit risk with possibility } \\
\text { of recovery }\end{array}$} & $\mathrm{CCC}+$ & Caa1 & $\mathrm{CCC}+$ & 5 \\
\hline & & $\mathrm{CCC}$ & $\mathrm{Caa} 2$ & $\mathrm{CCC}$ & 4 \\
\hline & & $\mathrm{CCC}-$ & Caa3 & CCC- & 3 \\
\hline & & $\mathrm{CC}$ & $\mathrm{Ca}$ & $\mathrm{CC}$ & 2 \\
\hline & & $\mathrm{C}$ & $\mathrm{C}$ & $\mathrm{C}$ & 1 \\
\hline & & DDD & DDD & DDD & 0 \\
\hline & & DD & DD & DD & 0 \\
\hline & & $\mathrm{RD}$ & $\mathrm{RD}$ & $\mathrm{RD}$ & 0 \\
\hline & Default & SD & RD & $\mathrm{RD}$ & 0 \\
\hline
\end{tabular}

Supplementary Information The online version supplementary material available at https:// doi.org/10.1057/s41308-021-00135-7.

\section{References}

Abadie, A. and G.W. Imbens. 2006. Large sample properties of matching estimators for average treatment effects. Econometrica 74: 235-267.

Aguiar, M. and G. Gopinath. 2006. Defaultable debt, interest rates and the current account. Journal of International Economics 69(1): 64-83.

Alesina, A. and D. Dollar. 2000. Who gives foreign aid to whom and why? Journal of Economic Growth 5: 33-63.

Alesina, A. and B. Weber. 2002. Do corrupt governments receive less Foreign aid? American Economic Review 92: 1126-1137. 
Bailey, M., A. Strezhnev and E. Voeten. 2015. Estimating dynamic state preferences from United Nations voting data. Journal of Conflict Resolution 61: 430-446.

Balima, W.H. 2017. Do domestic bond markets participation help reduce financial dollarization in developing countries? Economic Modelling 66: 146-155.

Balima, W.H., J.-L. Combes and A. Minea. 2017. Sovereign debt risk in emerging market economies: does inflation targeting adoption make any difference? Journal of International Money and Finance 70: 360-377.

Barro, R.J. and J.W. Lee. 2005. IMF-programs: who is chosen and what are the effects? Journal of Monetary Economics 52: 1245-1269.

Beers, D. and J. Mavalwalla. 2017. Database of sovereign defaults. Bank of Canada Technical Report 101: $1-35$.

Bird, G. 2001. IMF programs: do they work? can they be made to work better? World Development 29(11): 1849-1865.

Bird, G. and D. Rowlands. 2002. Do IMF programmes have a catalytic effect on other international capital flows? Oxford Development Studies 20(3): 229-249.

Borensztein, E. and U. Panizza. 2009. The costs of sovereign default. IMF Staff Papers 56(4): 683-741.

Boz, E. 2011. Sovereign default, private sector creditors, and the IFIs. Journal of International Economics 83: 70-82.

Caliendo, M. and S. Kopeinig. 2008. Some practical guidance for the implementation of propensity score matching. Journal of Economic Surveys 22: 31-72.

Chinn, M. and H. Ito. 2006. What matters for financial development? Capital controls, institutions, and interactions. Journal of Development Economics 81: 163-192.

Conway, P. 2006. The International Monetary Fund in a time of crisis: a review of Stanley Fischer's IMF essays from a time of crisis: the international financial system, stabilization, and development. Journal of Economic Literature 44: 115-144.

Corsetti, G., B. Guimaraes and N. Roubini. 2006. International lending of last resort and moral hazard: a model of IMF's catalytic finance. Journal of Monetary Economics 53: 441-471.

Cruces, J.J. and C. Trebesch. 2013. Sovereign Defaults: The Price of Haircuts. American Economic Journal: Macroeconomics 5(3): 85-117.

Cruz, C., Keefer, P., and Scartascini, C. 2016. Database of political institutions codebook, 2015 Update (DPI2015). Inter-American Development Bank, 1-28.

Das, U.S., M.G. Papaioannou and C. Trebesch. 2012. Sovereign debt restructurings 1950-2010: literature survey data, and stylized facts. IMF WP 12(203): 1-127.

Dhonte, P. 1997. Conditionality as an instrument of borrower credibility. IMF Paper on Policy Analysis and Assessment 2: 1-18.

Dicks-Mireaux, L., M. Mecagni and S. Schadler. 2000. Evaluating the effect of IMF lending to lowincome countries. Journal of Development Economics 61: 495-526.

Dreher, A. 2004. Does the IMF cause moral hazard? A critical review of the evidence. Unpublished paper 1-25.

Dreher, A., P. Nunnenkamp and M. Schmaljohann. 2015. The allocation of German aid: self-interest and government ideology. Economics \& Politics 27: 160-184.

Dreher, A. and J.-E. Sturm. 2012. Do the IMF and the World Bank influence voting in the UN General Assembly? Public Choice 151: 363-397.

Dreher, A. and S. Walter. 2010. Does the IMF help or hurt? The effect of IMF programs on the likelihood and outcome of currency crises. World Development 38(1): 1-18.

Eaton, J. and M. Gersovitz. 1981. Debt with potential repudiation: theoretical and empirical analysis. Review of Economic Studies 48(2): 289-309.

Eichengreen, B. 2015. Coping with global volatility: editor's introduction. International Economic Journal 30(3): 313-321.

Eichengreen, B., P. Gupta and A. Mody. 2006. Sudden stops and IMF-supported programs. IMF $w p$ 06(101): 1-51.

Fink, G. and S. Redaelli. 2011. Determinants of international emergency-humanitarian need only? World Development 35: 741-757.

Fink, F. and A. Scholl. 2016. A quantitative model of sovereign debt, bailouts and conditionality. Journal of International Economics 98: 176-190.

Fisher, S. 1997. Applied economics in action: IMF programs. American Economic Review 87(2): $23-27$. 
Gande, A. and D.C. Parsley. 2005. News spillovers in the sovereign debt market. Journal of Financial Economics 75: 691-734.

Gates, S. and A. Hoeffler. 2004. Global aid allocation: are Nordic donors different? CSAE wp 34: $1-34$.

Gündüz, Y.B. 2016. The economic impact of short-term IMF engagement in low-income countries. World Development 87: 30-49.

Hainmueller, J. 2012. Entropy balancing for causal effects: a multivariate reweighting method to produce balanced samples in observational studies. Political Analysis 20: 25-46.

Hardoy, I. 2003. Effect of IMF programmes on growth: a reappraisal using the method of matching. Paper presented at the European Economic Association, Stockholm, 20-24 August 2003.

Harrigan, J., C. Wang and H. El-Said. 2006. The economic and political determinants of IMF and World Bank lending in the Middle East and North Africa. World Development 34(2): 247-270.

Heckman, J. 1979. Sample selection bias as a specification error. Econometrica 47(1): 153-161.

IMF. 2018. Fiscal monitor: capitalizing on good times, April 2018, Washington

IMF. 2020. Resolving global debt: an urgent collective action cause, opening remarks by IMF First Deputy Managing Director Geoffrey Okamoto at the Peterson Institute for International Economics Conference, Washington

Jorra, M. 2012. The effect of IMF lending on the probability of sovereign debt crises. Journal of International Money and Finance 31(4): 709-725.

Kaminsky, G. and S.L. Schmukler. 2002. Emerging market instability: do sovereign ratings affect country risk and stock returns? World Bank Economic Review 16(2): 171-195.

Laeven, L. and F. Valencia. 2013. Systemic banking crises database. IMF Economic Review 61(2): $225-270$.

Levy-Yeyati, E. and U. Panizza. 2011. The elusive costs of sovereign defaults. Journal of Development Economics 94(1): 95-105.

Lin, S. and H. Ye. 2007. Does inflation targeting really make a difference? Evaluating the treatment effect of inflation targeting in seven industrial countries. Journal of Monetary Economics 54: 2521-2533.

Morris, S. and H.S. Shin. 2006. Catalytic finance: when does it work? Journal of International Economics 70(1): 161-177.

Mumssen, C., Y.B. Gündüz, C. Ebeke and L. Kaltani. 2013. IMF-supported programs in low income countries: economic impact over the short and longer term. IMF WP 13(273): 1-63.

Neuenkirch, M. and F. Neumeier. 2016. The impact of US sanctions on poverty. Journal of Development Economics 121: 110-119.

Panizza, U., F. Sturzenegger and J. Zettelmeyer. 2009. The economics and law of sovereign debt and default. Journal of Economic Literature 47(3): 651-698.

Papi, L., A.F. Presbitero and A. Zazzaro. 2015. IMF Lending and banking crises. IMF Economic Review 63: 644-691.

Przeworski, A. and J.R. Vreeland. 2000. The effect of IMF programs on economic growth. Journal of Development Economics 62(2): 385-421.

Puhani, P.A. 2002. The Heckman correction for sample selection and its critique. Journal of Economic Surveys 14(1): 53-68.

Pukthuanthong-Le, K., F.A. Elayan and L.C. Rose. 2007. Equity and debt market responses to sovereign credit ratings announcement. Global Financial Journal 18: 47-83.

Reinhart, C.M. 2002. Credit ratings, default, and financial crises? Evidence from emerging markets. World Bank Economic Review 16: 151-170.

Reinhart, C.M. and K.S. Rogoff. 2011. The forgotten history of domestic debt. Economic Journal 121(552): 319-350.

Reinhart, C.M. and K.S. Rogoff. 2014. This time is different: a panoramic view of eight centuries of financial crises. Annals of Economics \& Finance 15(2): 215-268.

Reinhart, C.M. and C. Trebesch. 2016. The international monetary fund: 70 years of reinvention. Journal of Economic Perspectives 30(1): 3-28.

Reusens, P. and C. Croux. 2017. Sovereign credit rating determinants: a comparison before and after the European debt crisis. Journal of Banking and Finance 77: 108-121.

Saravia, D. 2010. On the role and effects of IMF seniority. Journal of International Money and Finance 29(6): 1024-1044.

Staiger, D. and J.H. Stock. 1997. Instrumental variables regression with weak instruments. Econometrica 65 : 557-586. 
Suter, C. 1992. Debt cycles in the world-economy: Foreign loans, financial crises, and debt settlements. Westview Press, 1820-1990.

Sy, A.N. 2002. Emerging market bond spreads and sovereign credit ratings: reconciling market views with economic fundamentals. Emerging Market Review 3: 380-408.

Thacker, S.C. 1999. The high politics of IMF lending. World Politics 52(10): 177-213.

Tirole, J. 2002. Financial crises, liquidity, and the international monetary system. Princeton: Princeton University Press.

Tomz, M. and M. Wright. 2007. Do countries default in 'bad times'? Journal of the European Economic Association 5(2-3): 352-360.

Tudela, M., Duggar, E., Metz, A., and Oosterveld, B. 2011. Sovereign default and recovery rates, 1983-2010, Moody's Investors Service, May 10, 1-44.

Tweedie, A., Hagan, S., and Tiwari, S. 2012. Review of the fund's strategy on overdue financial obligations, IMF Policy Papers, August 20, 1-24.

Vaubel, R. 1996. Bureaucracy at the IMF and the World Bank: a comparison of the evidence. World Economy 19: 185-210.

Vreeland, J.R. 2002. The effect of IMF programs on labor. World Development 30(1): 121-139.

Zettelmeyer, J. 2000. Can official crisis lending be counterproductive in the short run? Economic Notes 29: $13-29$.

Publisher's Note Springer Nature remains neutral with regard to jurisdictional claims in published maps and institutional affiliations.

Hippolyte Balima is an economist at the IMF. Before joining the IMF, he worked for the World Bank's Macroeconomic and Fiscal Management Global Practice. He holds a Ph.D. in Economics from CERDIUniversity of Clermont Auvergne in France.

Amadou Sy is a Division Chief at the IMF's African Department. In addition to leading IMF missions to Cameroon, he is conducting research on financial sector issues, including FinTech, correspondent banking relations, and macrofinancial linkages. Amadou is also a nonresident senior fellow at the Africa Growth Initiative (AGI) at the Brookings Institution which he was leading until January 2017. Amadou holds a Ph.D. from McGill University. 